\title{
Intermediate field directions recorded in Pliocene basalts in Styria (Austria): evidence for cryptochron C2r.2r-1
}

\author{
Elisabeth Schnepp ${ }^{1 *}$ (D), Patrick Arneitz ${ }^{2}$, Morgan Ganerød ${ }^{3}$, Robert Scholger ${ }^{1}$, Ingomar Fritz ${ }^{4}$, Ramon Egli ${ }^{2}$ and \\ Roman Leonhardt ${ }^{2}$
}

\begin{abstract}
Pliocene volcanic rocks from south-east Austria were paleomagnetically investigated. Samples were taken from 28 sites located on eight different volcanoes. Rock magnetic investigations revealed that magnetic carriers are Ti-rich or Ti-poor titanomagnetites with mainly pseudo-single-domain characteristics. Characteristic remanent magnetization directions were obtained from alternating field as well as from thermal demagnetization. Four localities give reversed directions agreeing with the expected direction from secular variation. Another four localities of the KlöchKönigsberg volcanic complex (3) and the Neuhaus volcano (1) have reversed directions with shallow inclinations and declinations of about $240^{\circ}$ while the locality Steinberg yields a positive inclination of about $30^{\circ}$ and $200^{\circ}$ declination. These aberrant directions cannot be explained by local or regional tectonic movements. All virtual geomagnetic pole positions are located on the southern hemisphere. Four virtual geomagnetic poles lie close to the geographic pole, while all others are concentrated in a narrow longitude sector offshore South America $\left(310^{\circ}-355^{\circ}\right)$ with low virtual geomagnetic pole latitudes ranging from $-15^{\circ}$ to $-70^{\circ}$. The hypothesis that a transitional geomagnetic field configuration was recorded during the short volcanic activity of these five localities is supported by 9 paleointensity results and ${ }^{39} \mathrm{Ar} /{ }^{40} \mathrm{Ar}$ dating. Virtual geomagnetic dipole moments range from 1.1 to $2.9 \cdot 10^{22} \mathrm{Am}^{2}$ for sites with low VGP latitudes below about $60^{\circ}$ and from 3.0 to $9.3 \cdot 10^{22} \mathrm{Am}^{2}$ for sites with higher virtual geomagnetic pole latitudes. The new ${ }^{39} \mathrm{Ar} /{ }^{40} \mathrm{Ar}$ ages of $2.51 \pm 0.27 \mathrm{Ma}$ for Klöch and $2.39 \pm 0.03 \mathrm{Ma}$ for Steinberg allow for the correlation of the Styrian transitional directions with cryptochron C2r.2r-1 of the geomagnetic polarity time scale.
\end{abstract}

Keyword: Paleomagnetism, Paleointensity, Transitional field configuration, Cryptochron C2r.2r-1, ${ }^{39} \mathrm{Ar} /{ }^{40} \mathrm{Ar}$ dating, Styria (Austria), Volcanic rocks

\section{Introduction}

The Earth's magnetic field is generated in the outer core by an interacting system of liquid and electrical currents, which form the so-called geodynamo. For our understanding of the geodynamo knowledge of the temporal change of the geomagnetic field is crucial. Direct observations cover only a few hundred years (e.g., Arneitz et al.

\footnotetext{
*Correspondence: elisabeth.schnepp@unileoben.ac.at

1 Palaeomagnetic Laboratory Gams, Chair of Applied Geophysics,

Montanuniversität Leoben, Gams 45, 8130 Frohnleiten, Austria
}

Full list of author information is available at the end of the article
2017). Paleomagnetic records obtained from rocks provide information on the geological past (e.g., Gubbins and Herrero-Bervera 2007). Volcanic rocks give spot readings of the geomagnetic field and eventually provide a temporal succession if stratigraphy is known. In addition to the stable field configuration and its secular variation, documenting transitional field configurations during reversals or excursions are of high interest in order to constrain geodynamo mechanisms and support modeling of the geomagnetic field evolution during such critical events (e.g., Leonhardt et al. 2009). 
The geomagnetic polarity time scale (GPTS, e.g., Gradstein et al. 2012) is continually refined (Ogg et al. 2016). It is based on long sedimentary series obtained from ocean drilling and on records from lavas which are precisely correlated by astrochronology and radiometric dating (e.g., Channell et al. 2009; Singer 2014). The last $5 \mathrm{Ma}$ of the GPTS is divided into chrons and subchrons by more than 20 polarity transitions. Further instabilities, called cryptochrons or excursions, such as short-living or aborted reversals, are documented (e.g., Singer 2014).

Here, we present a re-investigation of sites from the Styrian volcanic field in south-east Austria for which paleomagnetic directions have been published some decades ago (Pohl and Soffel 1982; Mauritsch 1972; Table 1). While the Miocene sites showed normal directions in agreement with secular variation, the Pliocene sites (Bojar et al. 2013) yielded mainly inverse directions which do not lie within the range expected from secular variation. These anomalous directions observed in Styria potentially recorded excursional or transitional states of the geomagnetic field. In order to test this hypothesis, most sites have been resampled and new sites have been added. Here, full vector paleomagnetic data obtained with state-of-the-art demagnetization and paleointensity techniques are provided for the Pliocene volcanoes. New ${ }^{39} \mathrm{Ar} /{ }^{40} \mathrm{Ar}$ dating of two sites with transitional directions improved previous $\mathrm{K}-\mathrm{Ar}$ age constraints of Bojar et al. (2013) and support a correlation with the geomagnetic polarity time scale.

\section{Geological setting and field work}

The sampling area is located at the south-eastern margin of the Alps in the Styrian Basin (Fig. 1, Gross et al. 2007). It is part of the Pannonian Basin and separated from other sub-basins by the South Burgenland Swell in the south-east. The north-eastern boundary is built by a Penninic unit, while in the north, west and southwest the Styrian Basin is encircled by crystalline Austroalpine units and the Graz Paleozoic, which forms the basement as well. The formation of the Styrian Basin started in the Late Oligocene to Miocene at the final collision stage of the Adriatic and European plates and is connected to the alpidic lateral extrusion and subduction-related extension in the Pannonian region (e.g., Neubauer and Genser 1990). The sedimentary filling of the basin started in the Early Miocene and the major tectonic events were accompanied by volcanism producing volcaniclastics and high-K effusive rocks (Ebner and Sachsenhofer 1991). The second volcanic phase, starting in the Upper Miocene (Bojar et al. 2013), is dominated by a large number of tuff occurrences with phreatomagmatic origin (Pöschl 1991; Fritz 1996) and continued up to the Pliocene/Early Pleistocene with effusive alkaline rocks and volcaniclastic tuffs (Balogh et al. 1994). A total of 30-40 eruption centers have been identified (Kollmann 1965). The different volcaniclastic rocks prove the former presence of maars, scoria cones, lava lakes and lava flows. Today, exposed volcanic remnants (e.g., lava flows, diatremes) form prominent highs in the landscape (Gross et al. 2007). KAr ages and petrological description are available for six Pliocene lavas (see Table 1; Seghedi et al. 2004; Balogh et al. 1994).

Paleomagnetic sampling was carried out in several campaigns using an electrically or gasoline powered drill with diamond bit. The cores were orientated with a magnetic compass and whenever possible, with a sun compass. Azimuth differences between magnetic and sun compass readings were always $<5^{\circ}$. Samples were taken from 28 sites distributed over 8 volcanic units (see Table 1; Fig. 1). Two of the volcanic edifices have been sampled extensively: the Klöch-Königsberg complex, with samples taken in and around the big quarry of Klöch (KN01 to KN13) and at Zaraberg (KN14, KN15), and 3 dikes outcropping on the Königsberg tuff cone (Tieschen: TS, TD). Additionally, the synvolcanic lake sediment deposited on the top of the lavas in Klöch quarry was sampled with plastic boxes (Table 1). Another five sites were distributed over the big quarry Steinberg south of Mühldorf (SB01 to SB05). Directional results from six of our sites had already been published by Pohl and Soffel (1982) and were resampled at the same places or nearby.

\section{Rock and paleomagnetic laboratory procedures}

Thermomagnetic bulk susceptibility curves of crushed material, $\kappa(T)$, were measured in air using a MFK1-FA susceptibility meter (Agico) with a CS-3 temperature control unit. For a better understanding of the development of thermal alteration, the effects of thermal cycling with starting temperatures between $150-290{ }^{\circ} \mathrm{C}$ and increments of $100{ }^{\circ} \mathrm{C}$ were also investigated. Continuous thermal demagnetization was performed for a few mini-specimens drilled along the characteristic remanent magnetization direction in order to check for evidence of self-reversal magnetizations. Hysteresis and isothermal remanent magnetization (IRM) backfield curves were measured on mini-cores $(4-5 \mathrm{~mm})$ with a Micromag Model 3900 vibration sample magnetometer (VSM).

Characteristic remanent magnetizations obtained with stepwise alternating field (AF) as well as thermal demagnetization (except site KN10) have been measured with a cryogenic (2G) or a spinner (Agico JR6) magnetometer. $\mathrm{AF}$ demagnetization was performed in line with the magnetometer or with external devices (MI AFD 300, Magnon International, or ASC D-2000) while a MMTD60 or a MMTDSC furnace (Magnetic measurements) was used for thermal demagnetization. AF demagnetization 


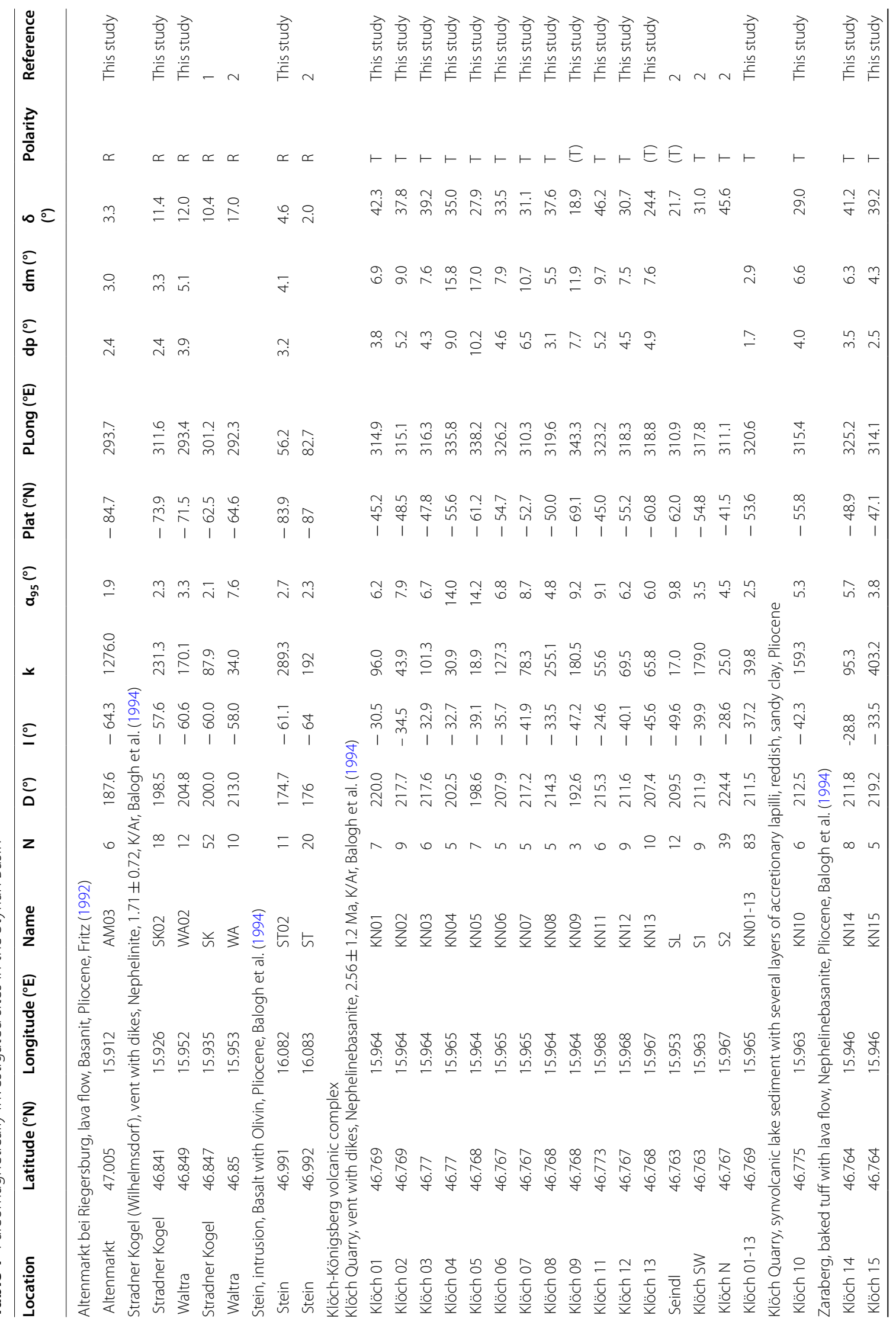




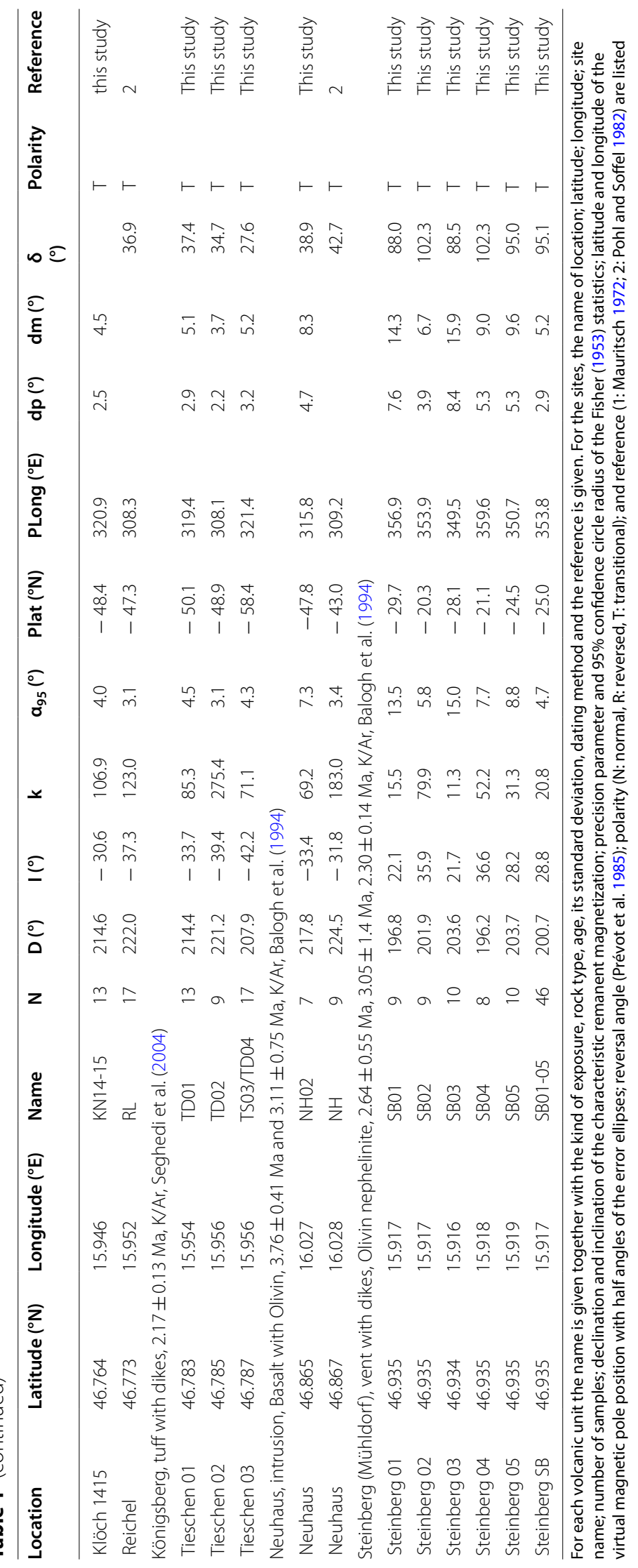




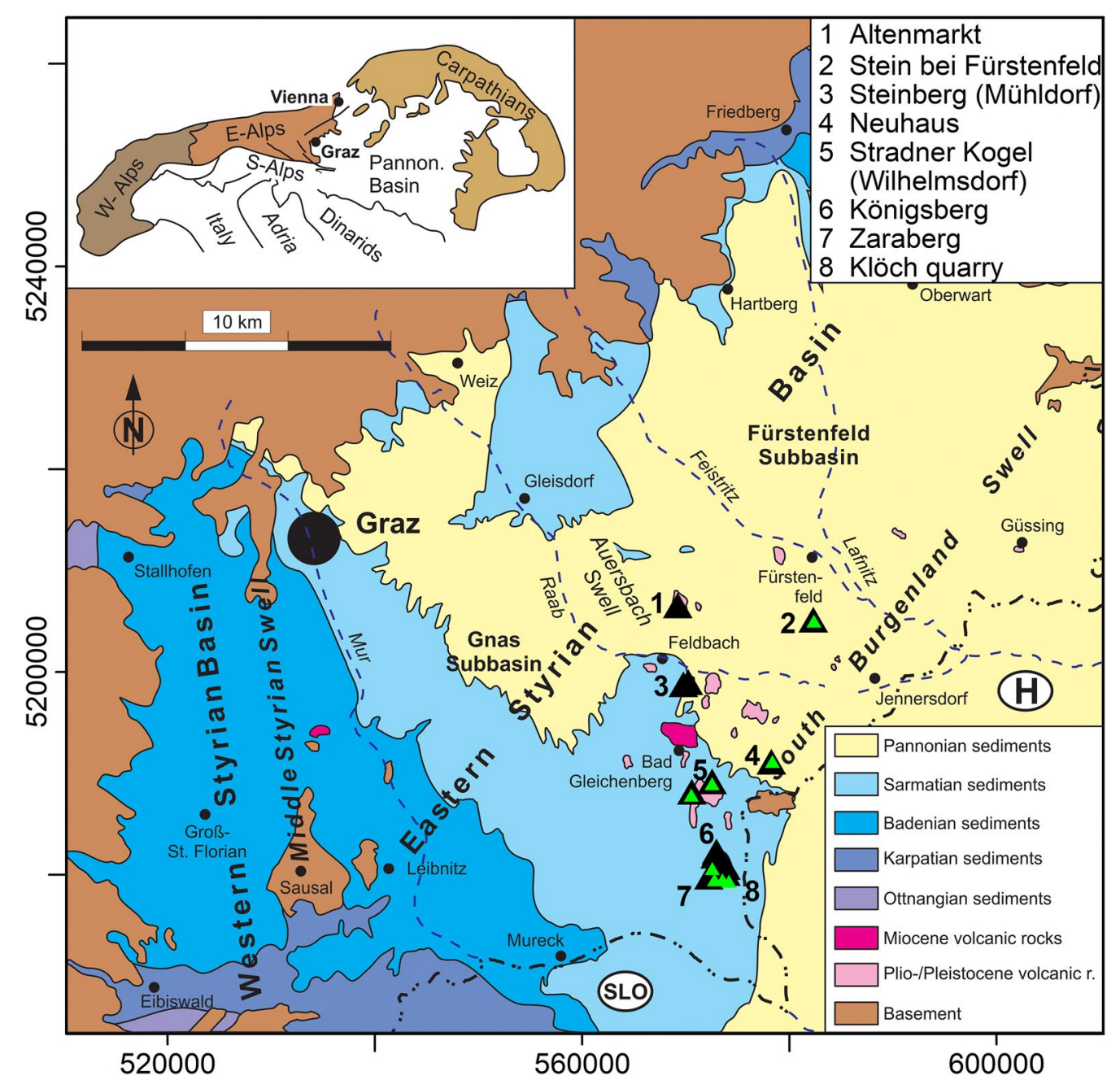

Fig. 1 Geological setting modified from Gross et al. 2007) and sampling locations of this study (black triangles) and of Pohl and Soffel (1982, green triangles)

was performed in 10-18 steps up to a maximum field of 140-300 $\mathrm{mT}$ depending on the behavior of the specimen and the equipment. Thermal demagnetization was based on $10-13$ steps between 100 and $600{ }^{\circ} \mathrm{C}$ with increments of 20,40 or $50^{\circ} \mathrm{C}$. The experiment was stopped when the residual magnetization was lower than $5 \%$ of the initial natural remanent magnetization (NRM) or an increase of magnetization was observed above $400{ }^{\circ} \mathrm{C}$.

Selection of well-suited specimens for paleointensity determination was difficult because rock magnetic experiments often revealed the presence of magnetic carriers with low thermal stability. Furthermore, viscous overprints, which hamper paleointensity determination have been detected in many samples. In addition to thermal stability of $\kappa(T)$-cycling and lack of viscous overprints, specimens for paleointensity determination were selected according to the absence or weakness of secondary components and remanence stability during thermal demagnetization. Temperature steps were adjusted to the expected unblocking temperatures and the onset of thermal alteration. Paleointensity experiments were conducted on 70 specimens (18 standard inch specimens and 52 mini-specimens of $9 \mathrm{~mm}$ diameter drilled from the inch specimens) from 14 sites (Additional file 1: Table S1). Thirteen sites were not tested because they failed the selection criteria given above. The Thellier technique modified by Coe (1967) using the protocol MT4 of Leonhardt et al. (2004) was applied. Thirteen to 15 heating steps starting at $90{ }^{\circ} \mathrm{C}$ or $200{ }^{\circ} \mathrm{C}$, depending on the expected blocking temperature range, have been used. Temperature increments comprised between 20 and $50{ }^{\circ} \mathrm{C}$ and the maximum temperature was $500{ }^{\circ} \mathrm{C}$, $550{ }^{\circ} \mathrm{C}$ or $\sim 600{ }^{\circ} \mathrm{C}$. A laboratory field between 15 and 40 $\mu \mathrm{T}$ adjusted to the expected intensity was applied. Six or 
7 pTRM-checks, 5 or 6 tail checks (Riisager and Riisager 2001) and 3-5 additivity checks (Krása et al. 2003) were included. Heating was performed in a MMTD24 furnace (magnetic measurements) using the rapid cooling rate setting, magnetization was measured with an AGICO JR-6A Dual Spinner Magnetometer and susceptibility was checked with a Bartington MS2B/MS3 Magnetic Susceptibility Meter ASC D-2000 after each temperature step. Because chemical alteration sometimes started before the secondary component was removed, Thellier experiments were combined with AF demagnetization for 42 specimens (Marshall et al. 1988) by applying a 15-mT AF demagnetization prior to each magnetization measurement (Additional file 1: Table S1). All paleointensity measurements were carried out at the Conrad Observatory (ZAMG).

\section{Isotopic dating}

Specimens from 4 of our sites were selected for ${ }^{39} \mathrm{Ar} /{ }^{40} \mathrm{Ar}$-dating, but inspection of thin sections revealed that only 2 sites provided material suited for dating.

The samples were crushed and sieved to obtain 180$250 \mu \mathrm{m}$ fractions. The finer particles were decanted in tap water and the coarser residue ultrasonically washed in acetone and deionized water several times. The optically best suited grains, void of any coatings, were handpicked under a stereomicroscope. The samples were packed in aluminum capsules together with the Taylor Creek Rhyolite (TCR) flux monitor standard along with zero age reagent grade $\mathrm{K}_{2} \mathrm{SO}_{4}$ and optical grade $\mathrm{CaF}_{2}$ salts for interference corrections. The samples were irradiated at the MTA reactor (Hungary) for $\sim 2 \mathrm{~h}$, with a nominal fast neutron flux density of c. $5.5 \times 10^{13} \mathrm{n} \cdot \mathrm{cm}^{-2} \cdot \mathrm{s}^{-1}$. The interference correction factors for the production of isotopes from $\mathrm{Ca}$ and $\mathrm{K}$ are reported in the Additional file 2: Table S2. The groundmass grains were placed in a 3.5- $\mathrm{mm}$ pit size aluminum sample disk and step heated using a defocused 3.5- $\mathrm{mm} \mathrm{CO}_{2}$ laser beam from Photon Machine Fusions 10.6 with a flat energy spectrum. The gases extracted from the sample cell were expanded into a Piston Free Stirling Cryocooler for trapping potential water vapor, and further expanded into a two-stage low volume extraction line $\left(\sim 300 \mathrm{~cm}^{3}\right)$. Both stages were equipped with SAES GP-50 (st101 alloy) getters, the first running hot $\left(\mathrm{c} .350{ }^{\circ} \mathrm{C}\right)$ and the second running at room temperature. The samples were analyzed with an MAP 215-50 mass spectrometer in static mode, installed at the Geological Survey of Norway. The peaks and baseline (AMU $=36.2$ ) were determined during peak hopping for 15 cycles (15 integrations per cycle, 30 integrations on mass $\left.{ }^{36} \mathrm{Ar}\right)$ on the different masses $\left({ }^{40-36} \mathrm{Ar}\right)$ on a MasCom electron multiplier (MC217) in analogue mode and linearly regressed back to zero inlet time. Blanks were analyzed every third measurement. After blank correction, a correction for mass fractionation, ${ }^{37} \mathrm{Ar}$ and ${ }^{39} \mathrm{Ar}$ decay and neutron-induced interference reactions produced in the reactor was performed using in-house software AgeMonster, written by Ganerød. This software implements the equations of McDougall and Harrison (1999) and the newly proposed decay constant for ${ }^{40} \mathrm{~K}$ after Renne et al. (2010). $\mathrm{A}^{40} \mathrm{Ar} /{ }^{36} \mathrm{Ar}$ ratio of $298.56 \pm 0.31$ from Lee et al. (2006) was used for the atmospheric argon correction and mass discrimination calculation using a power law distribution of the masses. Finally, we calculated J-values relative to an age of $28.619 \pm 0.036 \mathrm{Ma}$ for the TCR fluence monitor (Renne et al. 2010).

\section{Results}

\section{Rock magnetism}

The thermomagnetic behavior of susceptibility was measured for at least one sample per site. It was studied more intensively for the sites selected for paleointensity determination using also thermal cycling runs. The investigated samples yielded a broad spectrum of $\kappa(T)$-curves. These curves can be roughly divided into five types (Fig. 2).

Type A has a single, high Curie point $\left(T_{\mathrm{c}}\right)$ between 512 and $598{ }^{\circ} \mathrm{C}$ and can be almost completely reversible, which points to presence of magnetite as the dominant magnetic carrier. Irreversible curves are more common, with a susceptibility decrease to about half of the initial value (e.g., Additional file 5: Fig. S1, appendix: KN15-6). Thermal cycling shows that alteration starts above $450-500{ }^{\circ} \mathrm{C}$. In some cases, also a second

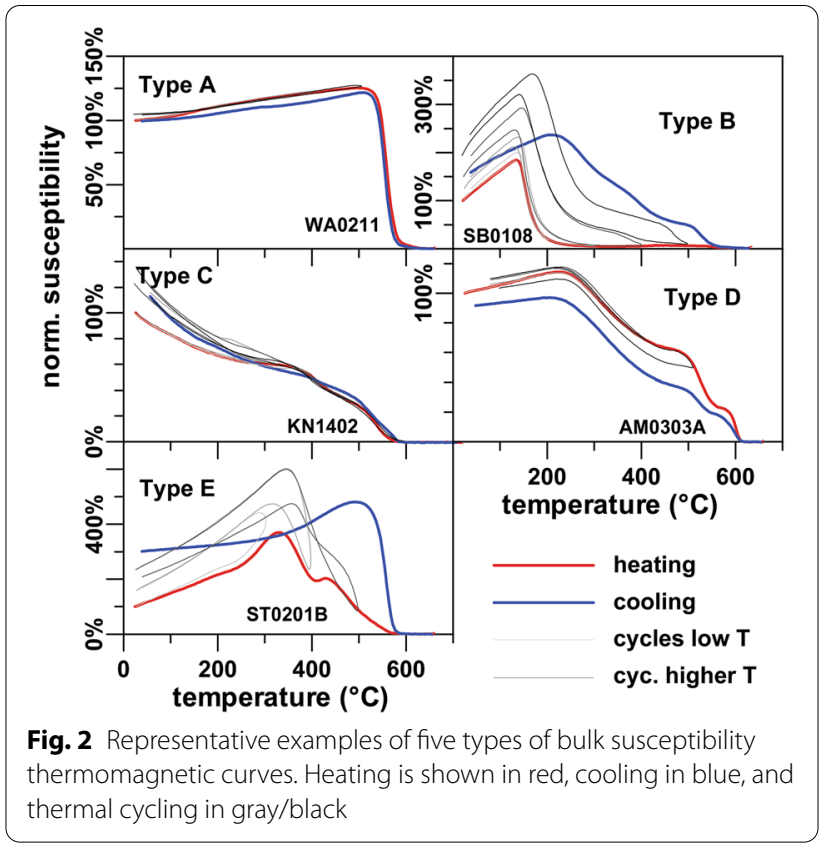


Curie point may occur at a higher temperature, pointing to the presence of some maghemite or hematite (e.g., Additional file 5: Fig. S1, KN12-7, SK0202B). Type A was found in only five localities (KN, TS/TD, SB, SK and WA, see also Additional file 5: Fig. S1, appendix and Additional file 3: Table S3).

The overwhelming majority of the sites showed a much less stable thermomagnetic behavior (Type B). It is characterized by the presence of a low Curie point, presumable carried by Ti-rich titanomagnetite, which transforms to magnetite when heated above $600{ }^{\circ} \mathrm{C}$. Curves can be almost reversible also at higher temperatures (e.g., Additional file 5: Fig. S1, KN06-2), but normally the formation of new magnetite is indicated by a bump present below $500{ }^{\circ} \mathrm{C}$ resulting in a new Curie temperature around $580{ }^{\circ} \mathrm{C}$ (Fig. 2 and e.g., Additional file 5: Fig. S1 KN04-5, KN08-5, NH0202I, SB0106I, SB0301, SB0507I, ST0209I). Thermal cycling shows that the onset of alteration starts already around $300{ }^{\circ} \mathrm{C}$. Heating to lower temperatures often yielded $T_{\mathrm{c}}$ values of $120-350{ }^{\circ} \mathrm{C}$. Type B samples are thus characterized by a highly variable Ti-content. Thermal alteration often prevented a proper estimation of $T_{\mathrm{c}}$. Thellier experiments of type $B$ specimens were performed from 90 to $360{ }^{\circ} \mathrm{C}$ in $30{ }^{\circ} \mathrm{C}$-steps, because thermal cycling often revealed good reversibility up to $400{ }^{\circ} \mathrm{C}$. Nevertheless, the presence of viscous overprints led to the failure of Thellier experiments for all tested type B specimens.

Type C shows a steady decrease of susceptibility with a high Curie point between 544 and $581{ }^{\circ} \mathrm{C}$ and some reversible curves were obtained. In the other cases, alteration is relatively weak, starts mostly around $500{ }^{\circ} \mathrm{C}$ (e.g., Additional file 5: Fig. S1, KN14-1O), and is visible mainly in the low $\left(<400{ }^{\circ} \mathrm{C}\right)$ temperature range. The susceptibility is relatively low and paramagnetic behavior is observed. This type is only present in one sample of SB02 (Additional file 5: Fig. S1) and site KN14, a tuff baked by the overlying lava flow KN15.

Type D shows three bumps both in heating and cooling curves, which may represent three magnetic carriers associated with Ti-rich and Ti-poor magnetite and/or maghemite. A proper $T_{\mathrm{c}}$ determination is possible only for the third decay and yields to values above $600{ }^{\circ} \mathrm{C}$. Such curves were only found in two sites: AM03 and TS03 (cf. Additional file 5: Fig. S1).

Finally, type E shows a mixture of two or three minerals and strong alteration. A high Curie point at $\sim 580^{\circ} \mathrm{C}$ indicates the formation of magnetite, while all other phases disappear. Stability against thermal cycling is low and alteration starts at about $300{ }^{\circ} \mathrm{C}$. Sites NH02 and ST02 were dominated by this behavior (cf. Additional file 5: Fig. S1).
Samples with $\kappa(T)$-types B and E were not used for paleointensity experiments, except for sites where better material was not available (cf. Additional file 3: Table S3).

Hysteresis parameters were measured with a VSM for 2-7 per site. The Day-diagram (Fig. 3; Additional file 4: Table S4) indicates that most samples plot in the lower part of the pseudo-single domain range close to the three mixing curves of SD and MD magnetite grains of Dunlop (2002).

\section{Paleomagnetic directions}

Directions of NRM are well constrained for only 8 sites (see Additional file 6: Fig. S2, appendix: AM03, SK02, ST02, WA02, KN01, KN12, KN14, KN15), while weak to significant secondary overprints are present at 20 sites indicated by moderate to considerable scatter of the NRM directions. Demagnetization experiments were done with AF (181 specimens) and thermally (142 specimens) and processed with the Remasoft 3.0 software in order to obtain the characteristic remanent magnetization (ChRM) directions from principal component analysis (PCA, Kirschvink 1980).

Figure 4a shows an almost ideal demagnetization behavior for site Altenmarkt without secondary components and a very good agreement between AF and thermal data. Site Stein (Fig. 4b) features only weak, easily removable secondary components and the ChRM directions are very well clustered (Additional file 6: Fig. S2). Sites Stradner Kogel (Fig. 4c) and Waltra (Fig. 4d) feature mostly clustered NRM directions and nearly antiparallel overprints, most likely originating from of the present

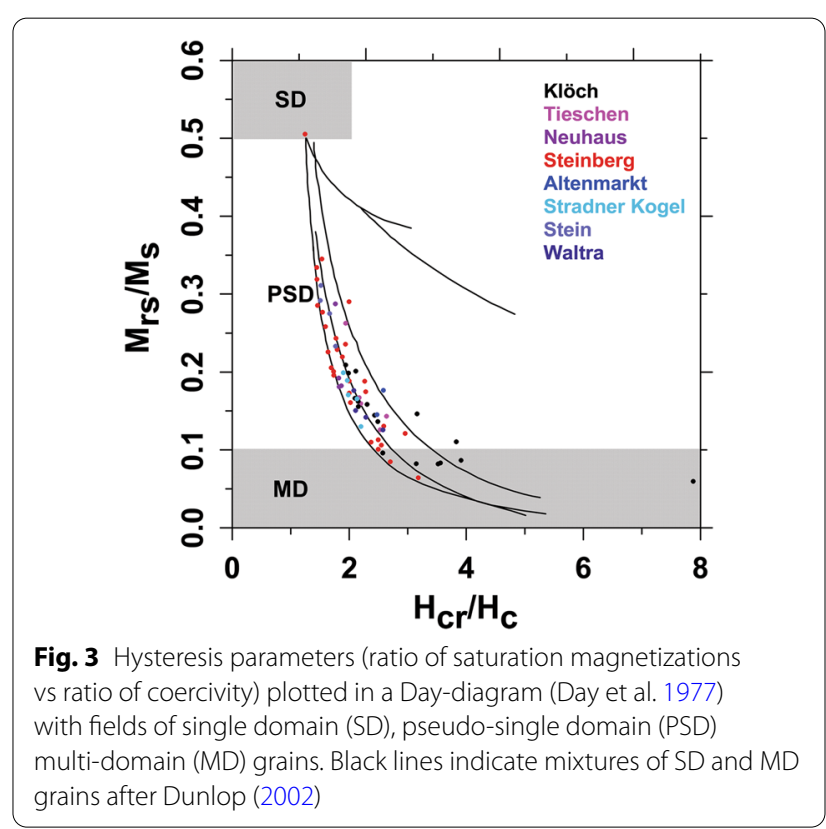



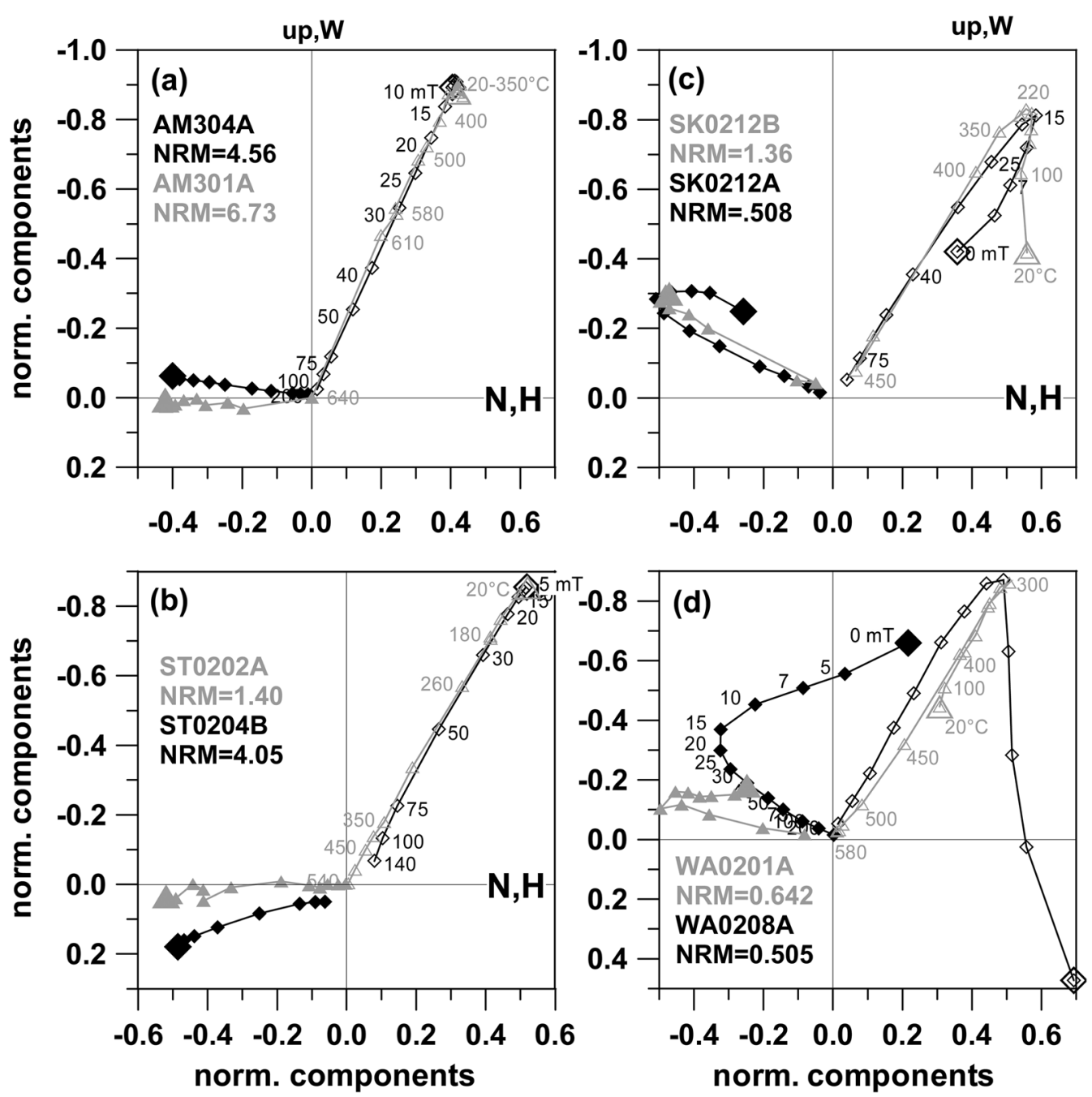

Fig. 4 AF (black) and thermal (gray) demagnetization results from a Altenmarkt, b Stein, c Stradner Kogel and d Waltra sites in orthogonal projections. NRM is indicated by a larger symbol. North component is plotted versus East component (closed symbol) and vertical component versus horizontal component (solid symbol). Numbers give demagnetization steps in $\mathrm{mT}$ or ${ }^{\circ} \mathrm{C}$. Specimen names are indicated and NRM intensity is given in $\mathrm{A} / \mathrm{m}$

geomagnetic field. Specimens with NRM directions far from the ChRM cluster have strong overprints which were removed with 5 to $30 \mathrm{mT}$ AF demagnetization (e.g., Fig. 4c, d).

Five sites were sampled at Steinberg volcano within a big quarry and NRM directions are very scattered with normal inclinations (Additional file 6: Fig. S2, SB01 to SB05). With the exception of two specimens, 5-30 mT or $75-200{ }^{\circ} \mathrm{C}$ were needed to remove secondary components (Fig. 5). Comparisons of these treatments with the median destructive field (MDF) and median destructive temperature (MDT) reveal that a large part of the magnetization was affected by secondary components (Additional file 7: Fig. S3, appendix: left). Scattered directions were often obtained during thermal demagnetization (Fig. 5b-d) along with chemical alteration, as suggested by a magnetization increase around $300{ }^{\circ} \mathrm{C}$ (e.g., Fig. 5a). Some specimens (13\%) were completely unstable and did not yield any ChRM. Valid ChRM directions are similar for all sites, but show a considerable dispersion (Table 1, Additional file 6: Fig. S2, SB01 to SB05).

Directions of the Klöch quarry and at Zaraberg sites are often affected by some scatter, with well-clustered ChRM directions being observed only in 2 cases (KN08, and KN15). Strong overprints were encountered in most of the demagnetization experiments. AF demagnetization with 5 to $30 \mathrm{mT}$ was sufficient to remove these secondary components, while elevated temperatures 

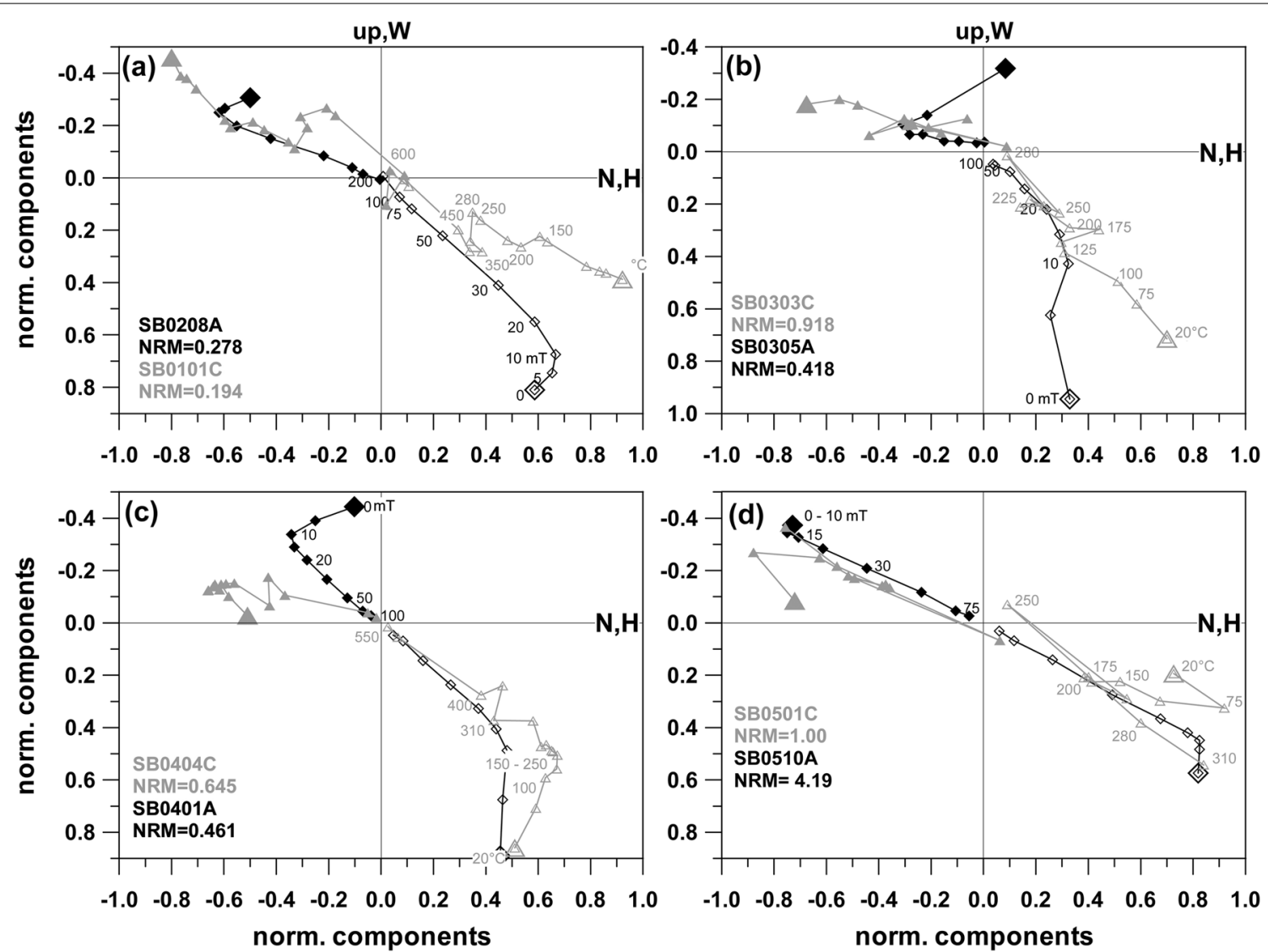

Fig. 5 Demagnetizations curves from the Steinberg site. Same representation as in Fig. 4

up to $380{ }^{\circ} \mathrm{C}$ were needed thermal demagnetization. Here MDT and MDF values (Additional file 7: Fig. S3, appendix: right) are generally higher than for Steinberg and some of the Klöch-sites have a good thermal stability with MDT values above $400{ }^{\circ} \mathrm{C}$. The origin of the secondary components was tested by great circle analysis with examples plotted in Fig. 6. They show that the demagnetization path leads to the present field direction. Accordingly, these overprints are viscous magnetizations caused by the present geomagnetic field. This was often but not always the case. Figure 7a, b shows demagnetization examples from Klöch for those sites which had only weak secondary components. The overprints are approximately antiparallel with an increase of intensity at the beginning of demagnetization, followed by straight lines with consistent directions. All sites from Klöch and Zaraberg have unusual ChRM directions with relatively low negative inclinations and declinations between $210^{\circ}$ to $230^{\circ}$ (Additional file 6: Fig. S2). The samples from the synvolcanic lake sediment layer (Table 1, KN10) showed well-defined clustered directions after removal of the viscous overprint, which are similar to those of the volcanic sites (Additional file 6: Fig. S2). Similar directions were

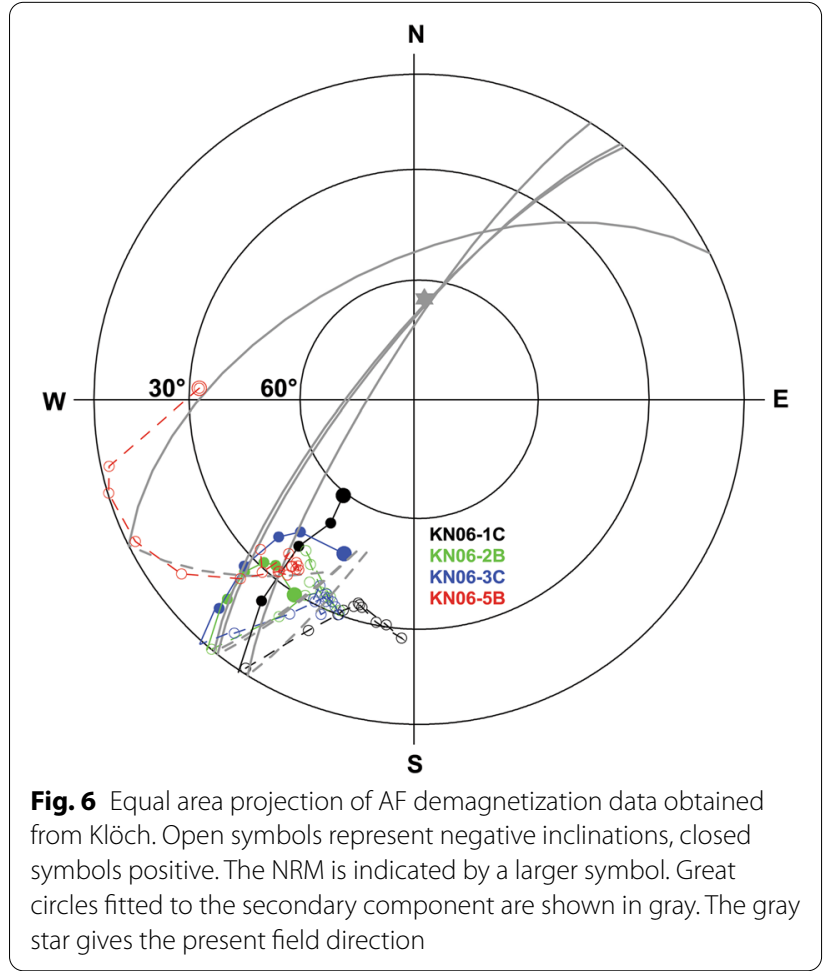



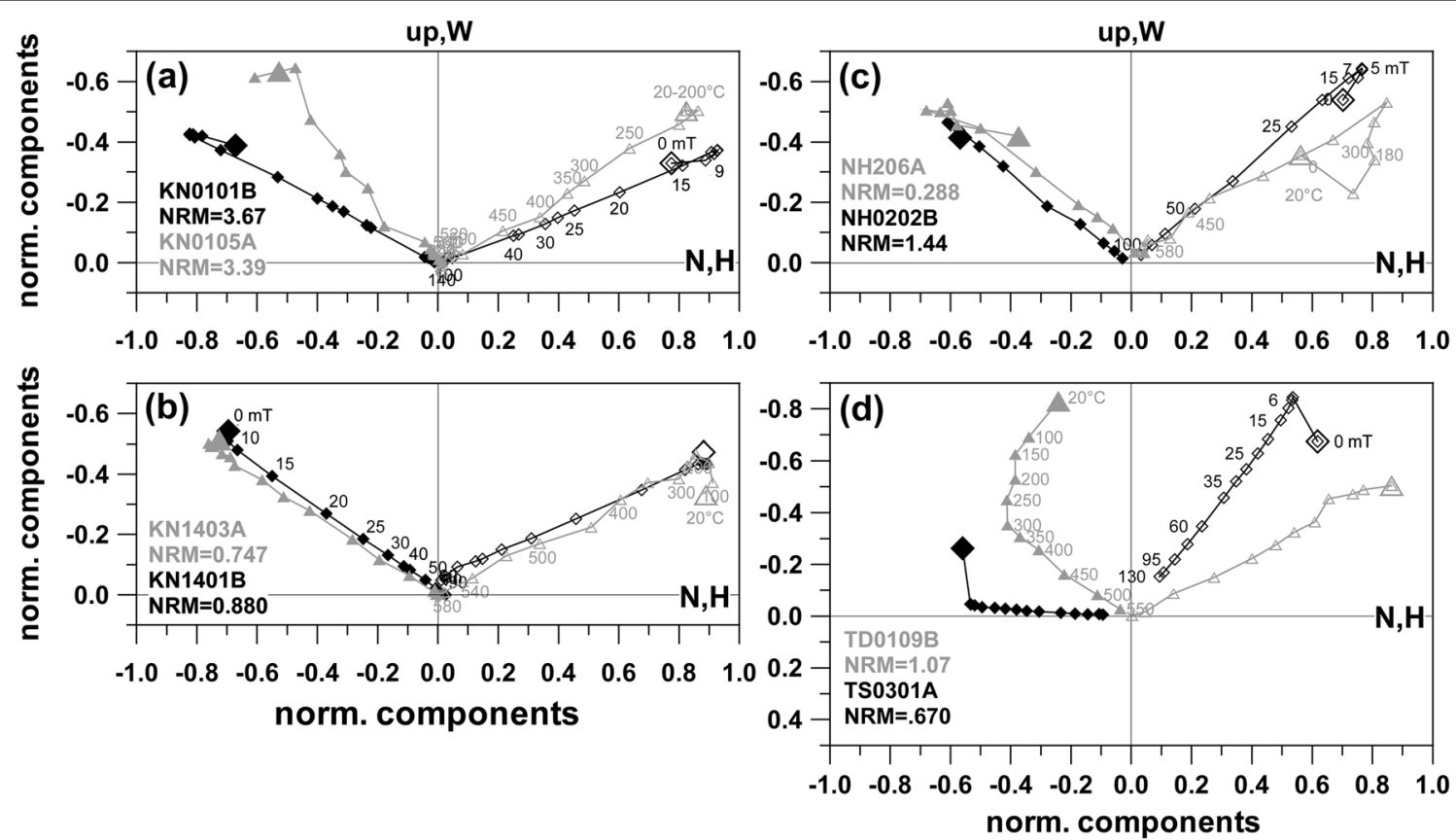

Fig. 7 Demagnetizations plots for a Klöch quarry, b Zaraberg, c Neuhaus and d Tieschen sites. Same representation as in Fig. 4

also observed for the lavas from Neuhaus and for three dikes in Königsberg north of the Klöch volcano (Additional file 6: Fig. S2, NH02 and TD01, TD02 TS03/TD04). The examples show moderate secondary overprints (Fig. 7c, d) and well-defined ChRM directions. Considerable directional scatter among samples is observed for all sites (Klöch, Zaraberg, Königsberg and Neuhaus) with these unusual directions (see Additional file 6: Fig. S2).

In summary, 28 well-defined ChRM directions have been obtained from $164 \mathrm{AF}$ and 111 thermal demagnetization experiments. Moreover, paleointensity experiments (see below) provided further 49 ChRM directions from the oriented specimens and mini-cores. The site mean directions were calculated hierarchically, averaging specimens of independently oriented samples first, and then sites using Fisher (1953) statistics. The statistical parameters and the mean ChRM directions are given in Table 1 and they are shown together with their confidence circles $\alpha_{95}$, NRM directions of specimens and ChRM directions of samples in Additional file 6: Fig. S2. For all sites the scatter of NRM directions was considerable reduced by the demagnetizations and well-defined mean ChRM directions are based on 5 (in one case only 3 ) to 18 independently oriented samples. Sites with unusual directions tend to have larger $\alpha_{95}$ circles.

\section{Paleointensities}

Evaluation of the paleointensity experiments started with determination of the ChRM direction, which failed for 11 specimens (Additional file 1: Table S1). A trend towards the laboratory field direction was also often observed. The ThellierTool4.22 software (Leonhardt et al. 2004) with default parameters for Classes $\mathrm{A}$ and $\mathrm{B}$ was used for preliminary evaluation and the results were checked carefully and sometimes adjusted, for instance by removing initial heating steps when they were obviously affected by an overprint. A few specimens, slightly exceeding class $B$ criteria but providing a good straight line fit, were also accepted (Class C). Another 27 specimens failed to give acceptable results.

For further characterization of our 37 results, additional parameters were calculated, such as the NRM fraction FRAC, the Arai plot curvature $\left|\vec{k}^{\prime}\right|$, and the correlation coefficient $R_{\text {corr }}^{2}$ (Additional file 1: Table S1, for definitions see Paterson et al. 2014, 2015). These parameters were checked with the software of Béguin et al. (2020). Three sets of criteria are used for the final classification (Table 2): the strict (S) criteria were based on the MC-CRIT.B1 set of Paterson et al. (2015). The same parameters are used for the moderate $(\mathrm{M})$ criteria based on the modified TTB set of Paterson et al. (2014). The third set takes the rather weak (W) criteria of Bono et al. (2019). Here only very basic requirements are fulfilled: A minimum of 5 steps is used for calculation of the slope in the Arai plot and linearity of the fit line is achieved by a correlation of $R^{2} \geq 0.9$; the zero field steps must have a trend to the origin with a maximum 
Table 2 Criteria sets were used for classification of the paleointensity results

\begin{tabular}{|c|c|c|c|c|}
\hline Criterion & Strict (S) & Moderate (M) & Weak (W) & Range \\
\hline$n$ & $\geq 5$ & $\geq 5$ & $\geq 5$ & $5-15$ \\
\hline FRAC & $\geq 0.45$ & $\geq 0.30$ & - & $0.19-0.97$ \\
\hline$\beta$ & $\leq 0.1$ & $\leq 0.1$ & - & $0.01-0.15$ \\
\hline q & $\geq 5$ & $\geq 3$ & - & $1.6-52.7$ \\
\hline$|\vec{k}|$ & $\leq 0.13$ & $\leq 0.48$ & - & $0.00-1.01$ \\
\hline$M A D_{\text {Anc }}$ & $\leq 6$ & $\leq 10$ & $\leq 10$ & $1.1-5.8$ \\
\hline a & $\leq 10$ & $\leq 15$ & - & $0.6-14.3$ \\
\hline DRAT & - & - & $\leq 10$ & $1.5-11.0$ \\
\hline$\delta C K$ & $\leq 7$ & $\leq 9$ & - & $1.2-6.8$ \\
\hline Spal & $\leq 9$ & $\leq 18$ & - & $0-40.8$ \\
\hline$\delta T R$ & $\leq 3.4$ & $\leq 20$ & - & $1.4-13$ \\
\hline$\Delta t^{*}$ & $\leq 9.0$ & $\leq 50$ & - & $0-7.3$ \\
\hline$R_{\text {corr }}^{2}$ & - & - & $\geq 0.9$ & $0.915-1.000$ \\
\hline Reference & Paterson et al. (2015) & $\begin{array}{l}\text { Modified from Paterson et al. } \\
\text { (2014) }\end{array}$ & Bono et al. (2019) & \\
\hline
\end{tabular}

$n$ : number of data points used for the linear fit; FRAC: NRM fraction; $\beta$ : standard deviation of slope; $q$ : quality factor (Coe et al. 1978$) ; \mid \vec{k}$ '|: Arai plot curvature; MAD Anc: maximum angular deviation of anchored line; $\alpha$ : angular difference between anchored and not-anchored solution; DRAT; deviations of pTRM checks; $\delta C K$ : pTRM checks; $\delta$ pal: cumulative check difference; $\delta$ TR: relative intensity difference of tail checks; $\Delta t^{*}$ : normalized tail of pTRM; $R_{\text {corr }}^{2}$ : correlation coefficient of fit line (for definitions see Paterson et al. 2014 and references therein). The last column gives the range of the values obtained for the successful experiments

angular dispersion of $<10^{\circ}$ and alteration assessed by PTRM checks must be $<10 \%$.

Representative examples for each set of criteria and one failed experiment are given in Fig. 8. Only 3 specimens fulfill the strict criteria (Fig. 8a), with very good linearity of the Arai plot and in the orthogonal vector plot of demagnetization, positive pTRM, additivity and tail checks and a very small error of the obtained paleointensity (Additional file 1: Table S1). Moderate criteria were fulfilled by 24 specimens. About half of them have also a good Arai plot linearity, but they do fail one to three of the $S$ criteria, which are often $\delta$ pal or $\delta T R$ and sometimes $\left|\vec{k}^{\prime}\right|$ or FRAC. The other specimens fulfilling $M$ criteria show concave Arai curves with an increase of TRM capacity and a trend towards the laboratory field direction, and in one case a decrease of TRM capacity followed by an increase (Fig. 8b, c). In these cases, slightly curved Arai plots were accepted over ranges where the alteration was still very low, as indicated by matching pTRM and additivity checks. Accordingly, the main parameters responsible for $S$ criteria failures were $\left|\vec{k}^{\prime}\right|$ and in a few cases FRAC, $\delta$ TR, $\delta$ pal or q. Ten specimens that met only the weak criteria are not particularly different in their behavior (Fig. 8d, e), but they do fail for $\left|\vec{k}^{\prime}\right|$ or FRAC and often they bear a considerable secondary component (Additional file 8: Fig. S4d). Some specimens failed because of a strong TRM capacity decrease above $400{ }^{\circ} \mathrm{C}$, which was followed by an increase due to the formation of new minerals (Fig. 8f).

\section{${ }^{39} \mathrm{Ar} /{ }^{40} \mathrm{Ar}$-dating}

Ar release spectra from incremental heating were obtained for 10 samples from 2 volcanic localities. Spectrum analysis criteria used to determine the sample ages include at least 3 overlapping consecutive steps (95\% confidence), accounting for $>50 \%$ cumulative ${ }^{39} \mathrm{Ar}$ release. An inverse isochron age was then calculated from these release steps and we use those results as sample ages. We chose this strategy since the isochron method does not contain any assumption regarding the trapped atmospheric contaminant.

(See figure on next page.)

Fig. 8 Examples of Thellier-Coe experiments shown in Arai plots with pTRM checks as triangles, and accepted steps as dots. The insets show orthogonal vector component projections in sample coordinates (vertical plane: open, blue symbols; horizontal plane: solid, red symbols, green line: mean direction associated with the chosen temperature interval). Further information can be found in Additional file 3: Table S3 and Additional file 8: Fig. S4 
(a) Strict

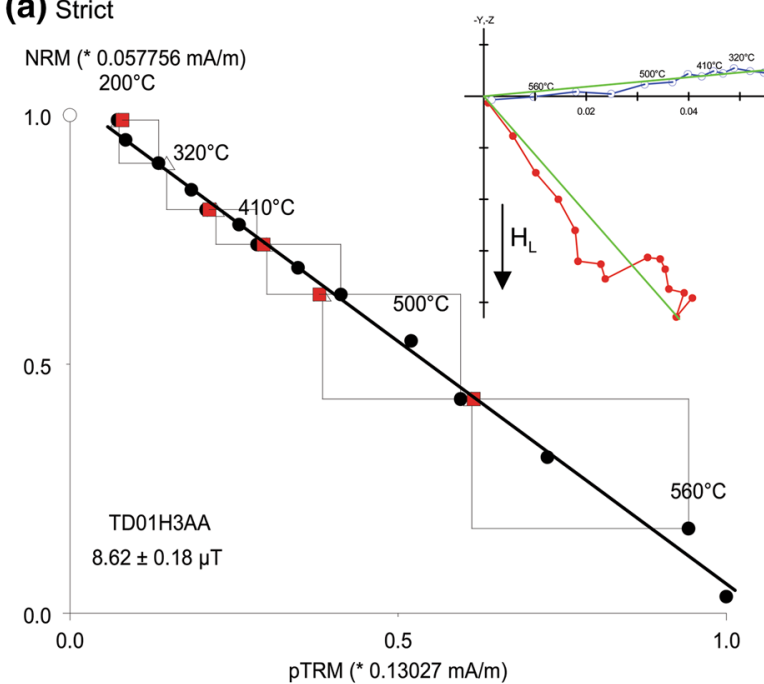

(b) Moderate

(c) Moderate

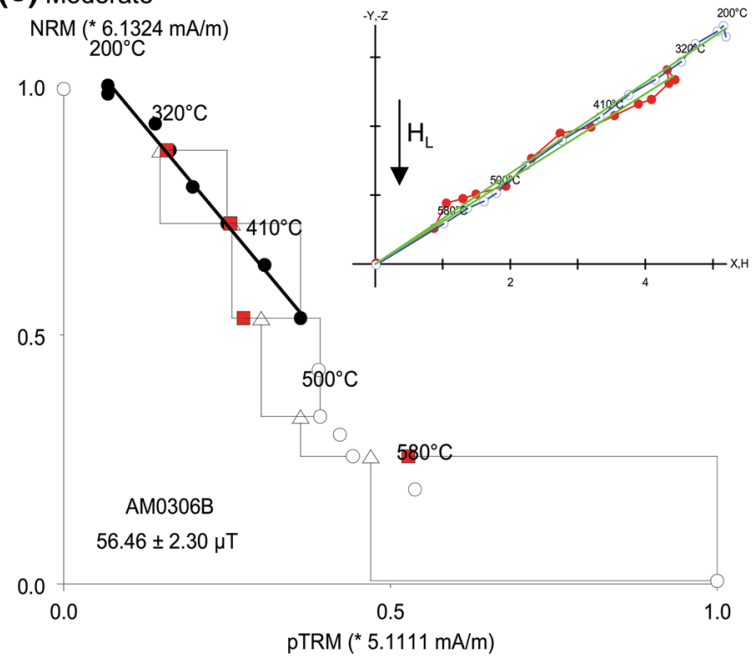

(d) Weak

NRM (*0 $0.10479 \mathrm{~mA} / \mathrm{m}$ )
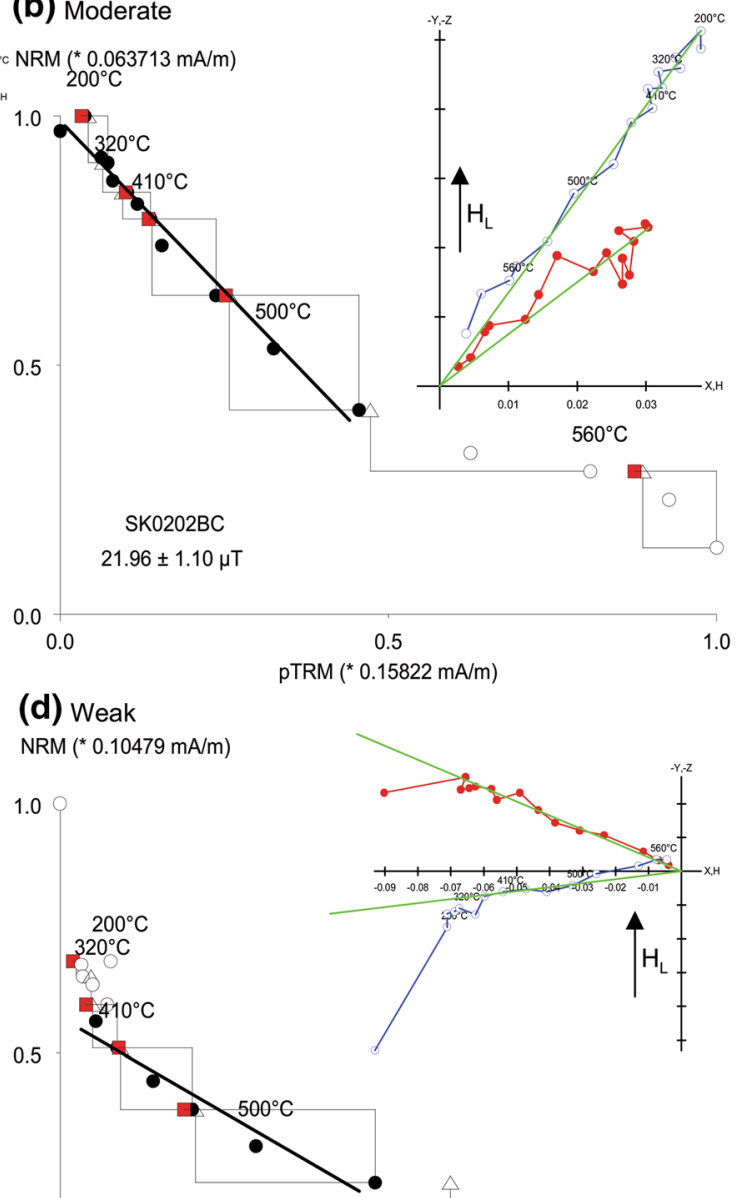

SK0202BC

$21.96 \pm 1.10 \mu \mathrm{T}$

0.0
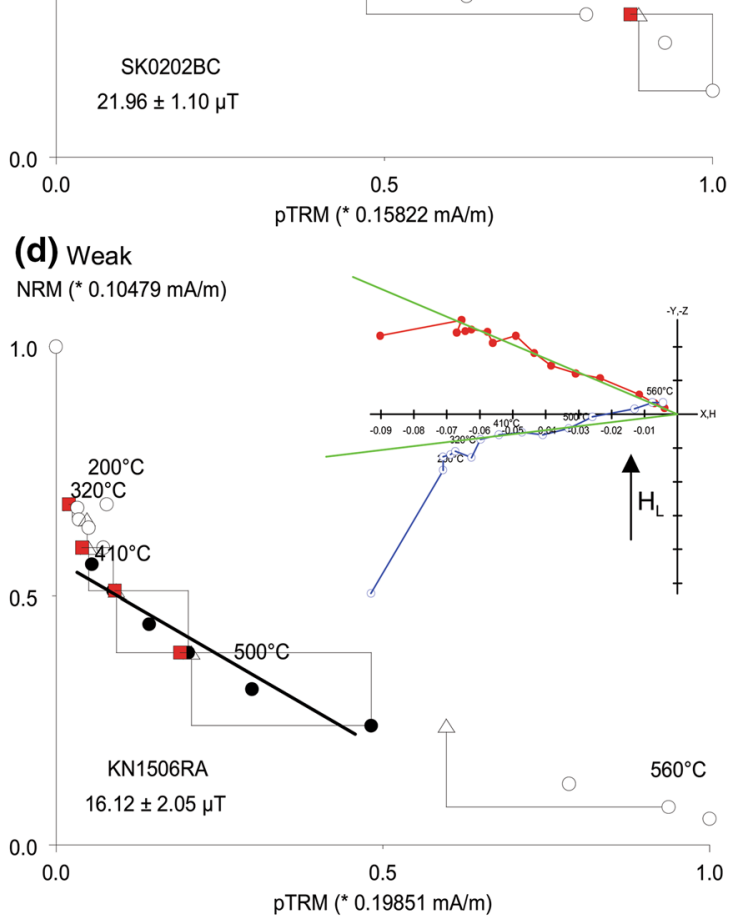

(e) Weak

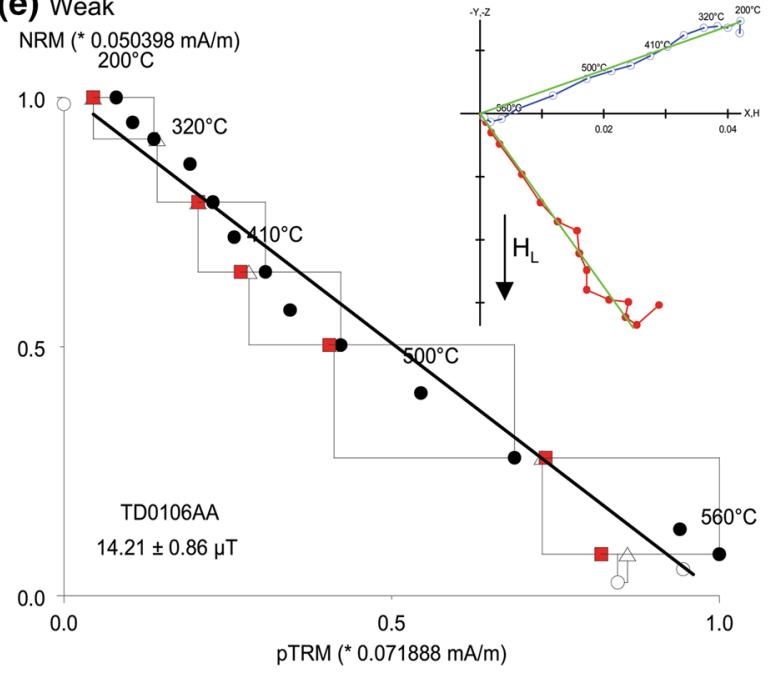

(f) failed

NRM ( $\left.{ }^{*} 0.11191 \mathrm{~mA} / \mathrm{m}\right)$

$1.0 \bigcirc 200^{\circ} \mathrm{C}$
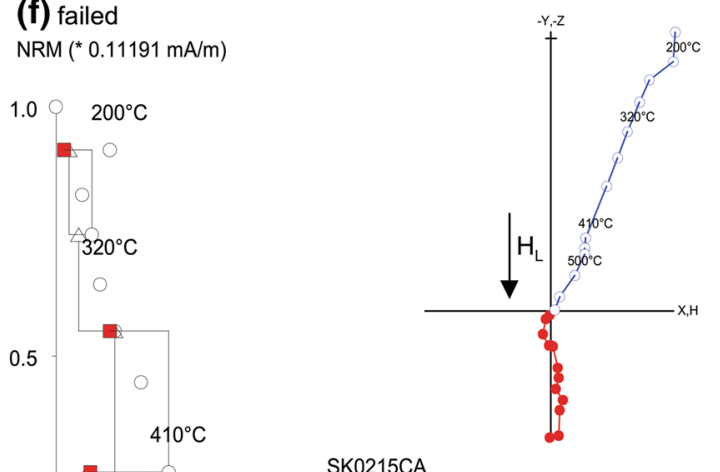

SK0215CA
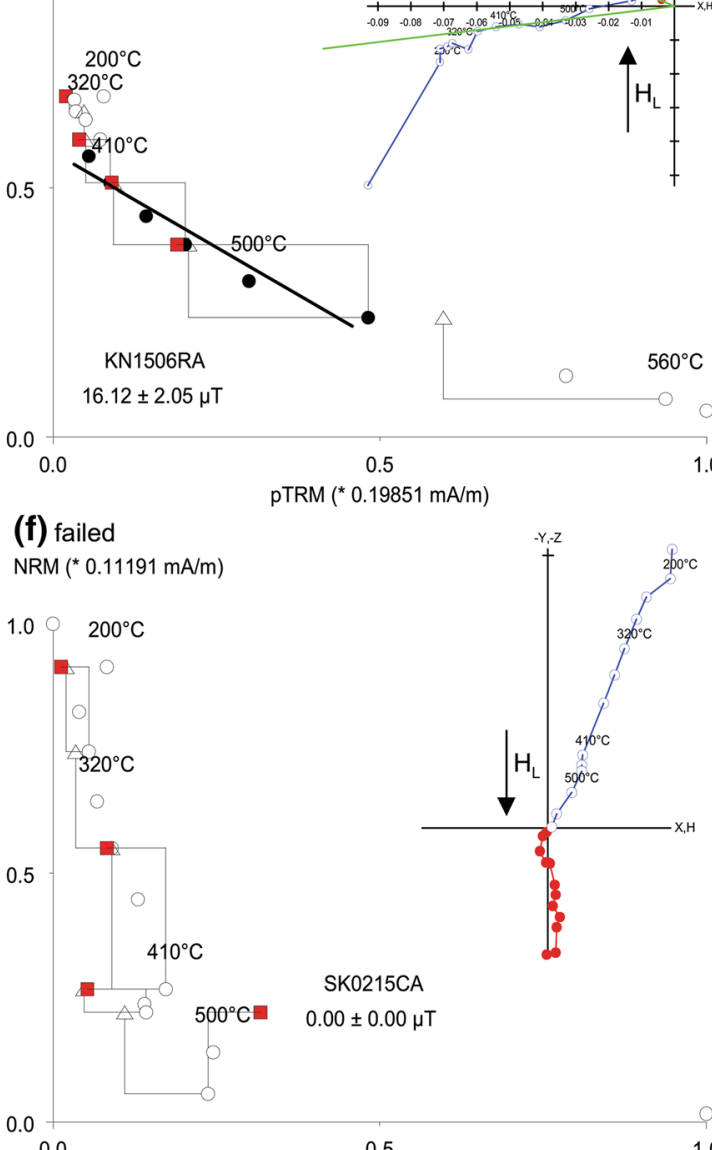

0.5

pTRM $\left({ }^{*} 0.26913 \mathrm{~mA} / \mathrm{m}\right)$

Fig. 8 (See legend on previous page.) 


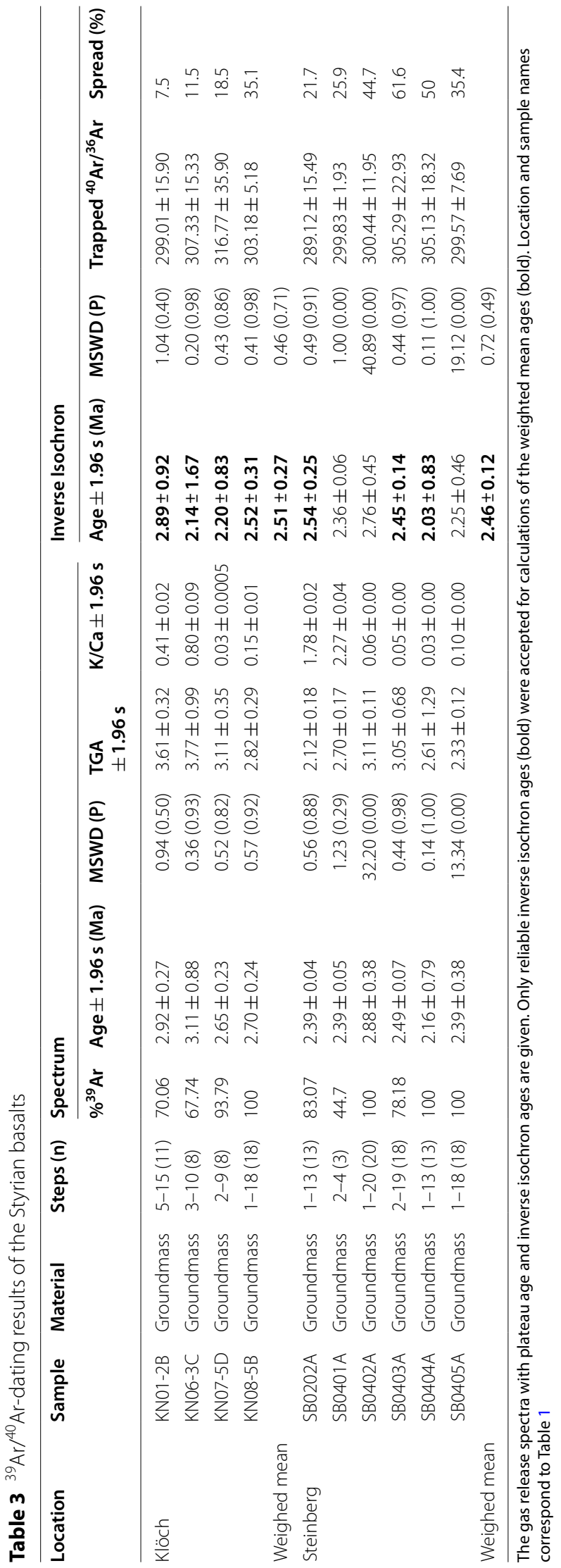


The gas release spectra with inverse isochrons are displayed in Table 3 and Additional file 9: Fig. S5. The release spectra of all samples from Klöch contain a plateau. Inverse isochron results yield an inverse weighted mean age of $2.51 \pm 0.27 \mathrm{Ma}$ (MSWD: 0.46, P: 0.71). Only 3 samples from Steinberg met the aforementioned age criteria (SB0202A, SB0403A and SB404A) with an inverse weighted mean age of $2.46 \pm 0.12$ (MSWD: 0.72, P: 0.49).

\section{Discussion}

\section{Mean paleomagnetic directions and virtual geomagnetic poles}

Most specimens showed weak-to-strong secondary overprints. In almost all cases, an increase of the intensity at the beginning of the demagnetization experiments suggests that the secondary component has an approximately antiparallel direction. Because all sites have ChRM directions nearly opposite to the present-day field, secondary components are most likely viscous overprints. This is supported by the fact that, for many specimens, great circles fitted to the secondary component run through the present field direction. The magnetization increase with respect to the NRM was considerable, often exceeded $30 \%$ of the initial NRM intensity. Accordingly, specimens with a pure primary TRM, which is a prerequisite for paleointensity determination, were rare.

Secondary components were mostly removed with $\leq 30$ $\mathrm{mT}$ AF demagnetization, while $300{ }^{\circ} \mathrm{C}$ or even more were required during thermal demagnetization. In most cases well-defined mean ChRM directions were obtained (Table 1) with values of the precision parameter $k$ (Fisher 1953) ranging from 11 to 1276, and $\alpha_{95}$ values between $2^{\circ}$ and $15^{\circ}$. Sites having strong secondary overprints indicated by large dispersions of the NRM directions (cf. Table 1 and Additional file 6: Fig. S2, e. g. Klöch quarry: KN11 or Steinberg: SB01 to SB05) often yield mean ChRM directions with relatively low $k$ values. The mean ChRM directions of only 4 sites are reversed and within the range of secular variation (Fig. 9). The remaining sites show anomalous directions confined to the from 190 to $240^{\circ}$ declination sector. Sixteen sites have low negative inclinations and 5 sites have low positive inclinations. The confidence circles are generally larger for sites with intermediate directions and the large dispersion of NRM directions indicate outweighing of strong secondary components. Nevertheless, magnetic cleaning was successful and provided well-defined reliable mean ChRM directions.

Calculation of the reversal angle $\delta$ (Prévot et al. 1985) and the virtual geomagnetic poles (VGP, Table 1 and Fig. 10) shows that all sites have reversed polarities and only 4 sites cluster close to the geographic pole having high VGP latitudes $\left(<-70^{\circ}\right.$ see Table 1 , cluster A in Fig. 10) and a reversal angle $\delta<25^{\circ}$. Furthermore, VGPs are mainly confined in a narrow longitudinal sector from 290 to $360^{\circ} \mathrm{E}$. Two more clusters with low VGP latitudes can be identified, one (cluster B) at about $-45^{\circ}$ and another (cluster $\mathrm{C}$ ) below $-30^{\circ}$. Other sites from Klöch and Zaraberg investigated by Pohl and Soffel (1982) fall also in this cluster and the poles of Pohl and Soffel (1982) are well reproduced (Table 1; Fig. 10). While for cluster $C \delta$ angles exceed $80^{\circ}$ for cluster B they range from $18.9^{\circ}$ to $46.2^{\circ}$. This VGP distribution obviously does not represent secular variation. Accordingly, the possibility of tectonic movements must be taken into consideration. In this case, the recorded anomalous directions would require a $\sim 30^{\circ}$ rotation of the Klöch-Königsberg and Neuhaus volcanoes and an even larger rotation for Steinberg. The lavas of two volcanoes are well exposed in large quarries and there is no geological evidence for local displacements or regional movements affecting all 5 localities with unusual directions. Sites with directions in the range of SV and those with anomalous directions are distributed all over the volcanic field and no correlation with tectonic features is found (Fig. 11). For instance, Klöch and Königsberg are separated by a normal fault, but the paleomagnetic directions are very similar. Furthermore, the synvolcanic lake sediment layer (Table 1, KN10) yielded a ChRM direction within the cluster of the Klöch-Königsberg lavas. The detritus came very likely from volcanic ejection of the Königsberg, which implies also a stratigraphic constraint between the Klöch and Königsberg lavas. The sediment is layered nearly horizontally, displays the visible underlying morphology and does not give evidence for local tectonic movements. Furthermore, the similar directions of Klöch-Königsberg complex and Neuhaus volcano would require the same local tectonic movement to explain their unusual but very similar directions, which is rather unlikely. Finally, the Miocene Gleichenberg volcano (in blue in Fig. 11) recorded normal polarity directions in the range of secular variation (Pohl and Soffel 1982). Accordingly, a large-scale tectonic rotation after the Miocene can be excluded for the area.

Therefore, the only remaining conclusion is that the Styrian volcanoes recorded intermediate field directions. Following Prévot et al. (1985), a reversal angle $\delta>25^{\circ}$ can be attributed to a transitional field direction. Accordingly, the sites of cluster $\mathrm{C}$ are clearly transitional. However, three sites (KN09, KN13, SL) in cluster B have $\delta<25^{\circ}$ (Table 1). Due to their close temporal proximity to the other sites of cluster $B$ recording of a transitional field configuration seems to be plausible. This hypothesis was further tested by investigation of the paleointensity. 


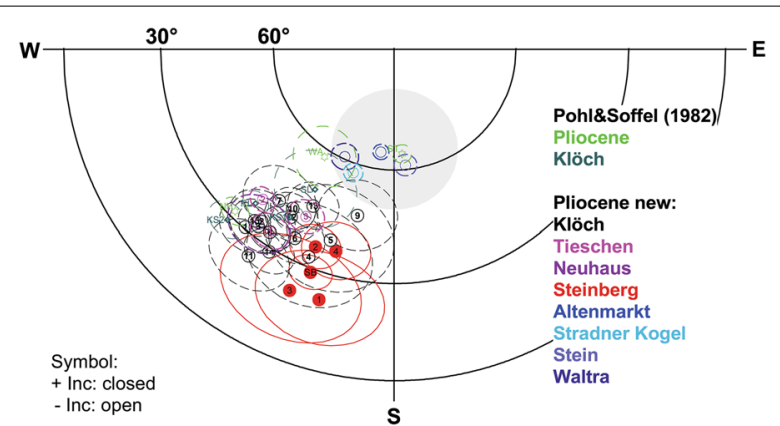

Fig. 9 Mean characteristic remanent magnetzations and $a_{95}$ of the Styrian volcanic rocks. The gray area shows the expected of secular variation. Data from Pohl and Soffel (1982) are shown for comparison

\section{Paleointensity}

Paleointensity determination was difficult, due to secondary components and chemical alteration during heating. Thellier experiments were performed for 15 sites and the failure rate was about $50 \%$. Only 3 specimens fulfill the strict MC-CRIT.B1 criteria set of Paterson et al. (2015), while for the moderate criteria set, the NRM fraction FRAC was lowered to 0.3, considerably less than recommended by Paterson et al. (2014, 2015: 0.45). FRAC (see Shaar and Tauxe 2013) was introduced instead of the fraction factor $f$ (Coe et al. 1978) because $f$ may be overestimated in case of strongly concave Arai plots. This behavior is caused by the presence of a large amounts of MD particles, but also by strong viscous overprints. Viscous overprints have been often observed during our paleointensity experiments, for instance for the specimen shown in Fig. 8d, which lost about one-third of the NRM during the first heating step in combination with AF demagnetization. This loss was accompanied by a strong directional change. $\kappa(T)$ (Additional file 5: Fig. S1) gives no indication for the presence of a mineral with low Curie temperature. While the secondary component is

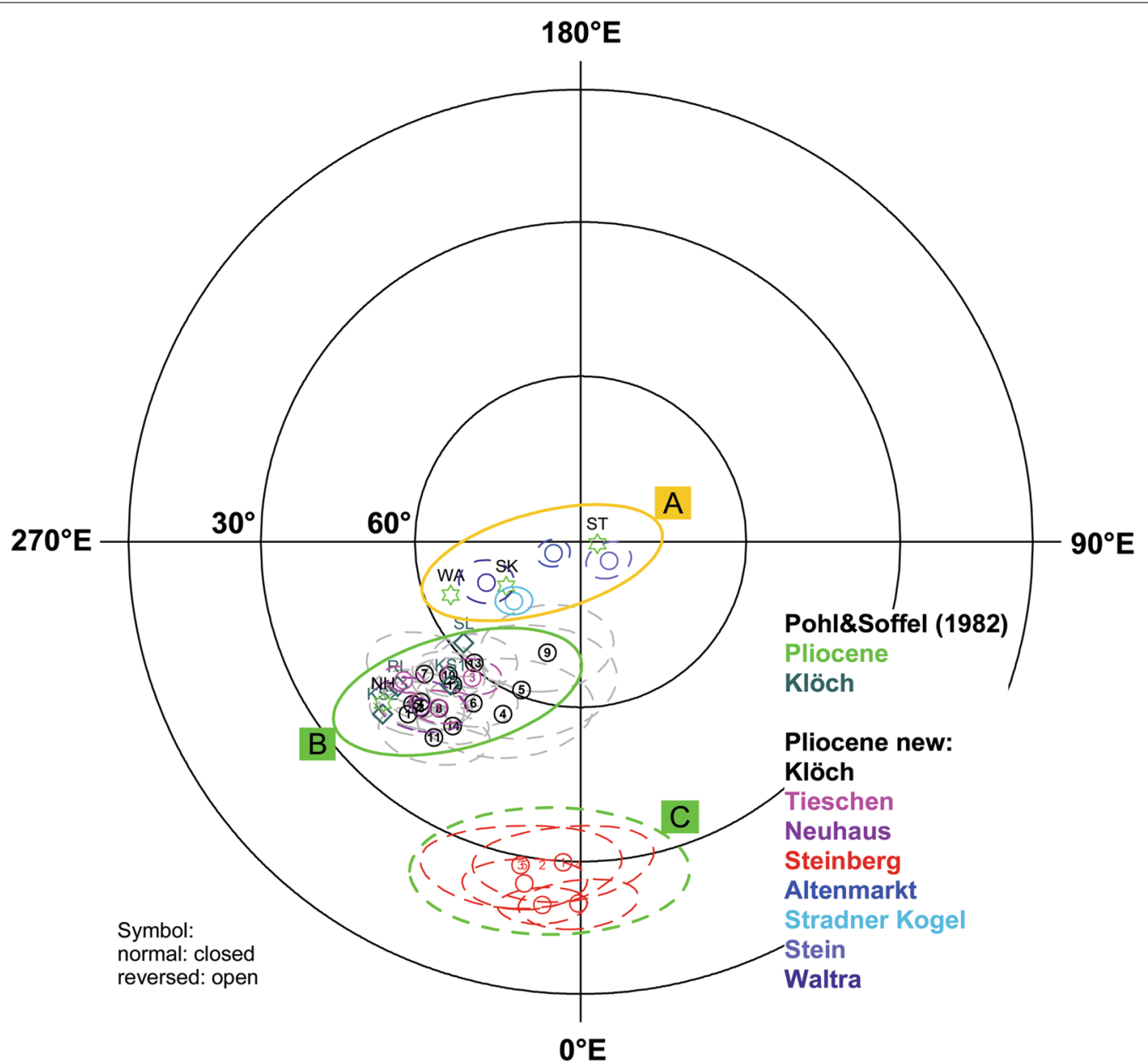

Fig. 10 Mean virtual geomagnetic pole (VGP) positions obtained in this study (circle, with error ellipses) in comparison with data of Pohl and Soffel (1982, green stars). Three clusters were identified (see text for details) 


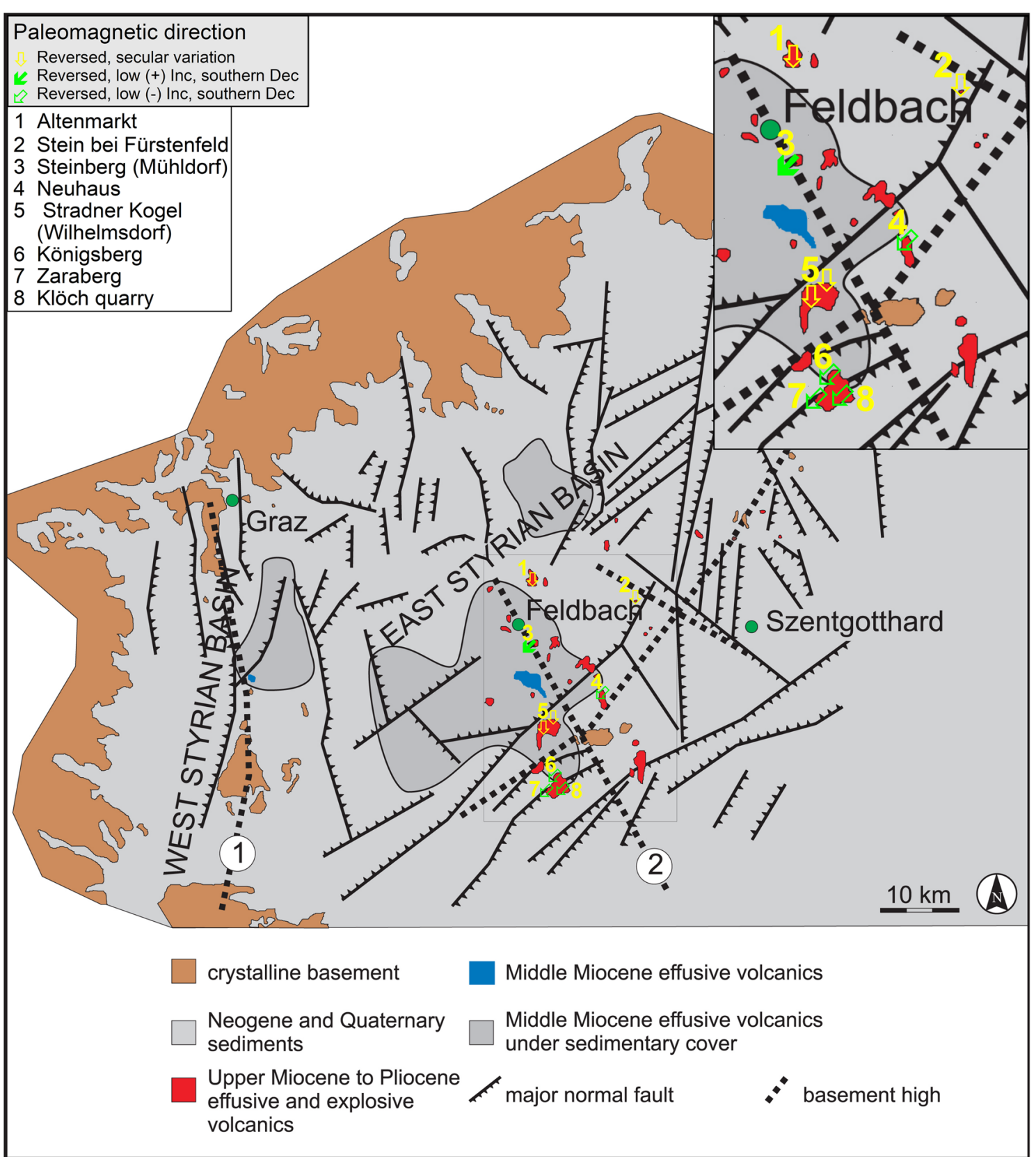

Fig. 11 Map of the Styrian basin showing main geological units, and tectonic and volcanic features ( modified from Bojar et al. 2013). Paleomagnetic sites and results are included

still present until $350{ }^{\circ} \mathrm{C}$, very little TRM is gained in the Thellier experiment. The viscous component was relatively large compared to the paleo-TRM because this TRM was acquired in a much weaker field than the present-day value. The fraction factor $f$ is $>0.5$ for this example (Additional file 1: Table S1) and, although somewhat overestimated, $f$ appears to be more appropriated than FRAC in such cases. The hysteresis parameters of this specimen point also to a large MD fraction, which explains the strong curvature $\left|\overrightarrow{\mathrm{k}^{\prime}}\right|$ in the Arai plot. Mineral alteration starts at $\sim 500^{\circ} \mathrm{C}$ (Additional file 5: Fig. S1), as shown by the last pTRM check. Accordingly, the selected data points give a reasonable paleointensity estimate and this is also the case for the example in Fig. 8 e. It is obvious that most of our samples do not have magnetic properties which are suited to provide very precise 
paleointensities. Instead, the aim of the study is rather to find support for the intermediate character of the directions by intensity measurements and thus to have more indications for a transitional field configuration. Hence, many of the results which we take into consideration allow only for a rough assessment of paleointensity and do not fulfill the various published and widely accepted more strict criteria (e.g., Kissel and Laj 2004,2015; Biggin et al. 2007; Paterson et al. 2014; Cromwell et al. 2015; Tauxe et al. 2016). Although such reliability criteria sets are undoubtedly useful for statistical investigation for long-term trends of the field, a too rigorous application rejects many experiments which could yield slightly uncertain, but important information about the paleofield configuration.

Finally, paleointensity results from 10 sites are taken into consideration and 9 mean paleointensity values have been calculated (Table 4), in one case by combining single values for 2 sites from Steinberg volcano. These mean values are robust and remain within their error margins when a stricter selection (only strict and moderate criteria accepted) is made (Additional file 1: Table S1).

Figure 12 shows a summary of all accepted paleointensity results together with the site means. A large variation of paleointensities is seen between the sites, while the within-site dispersion is considerably smaller.

Data in Fig. 12 are grouped according to the above described VGP clusters. Class M paleointensity results are present in all groups and the class $\mathrm{W}$ results do not show larger deviations. Paleointensities of sites with low VGP latitudes lie in the range from 8 to $13 \mu \mathrm{T}$ and only $5 \mu \mathrm{T}$ has been determined for the lowest VGP latitudes. These values are relatively low compared with the field intensity which was on average about $35 \pm 8 \mu \mathrm{T}$ for the past $5 \mathrm{Ma}$ (Muxworthy 2017). While one site with high VGP latitude has a relatively large intensity of $57 \mu \mathrm{T}$, the values from the Stradner Kogel sites are only around 20 $\mu \mathrm{T}$ and not much higher than those of the transitional sites. The Stradner Kogel VGPs lie relatively close to cluster $\mathrm{B}$ and the reversal angles are above $10^{\circ}$. This could suggest that the Stradner Kogel sites were formed shortly before or after the sites of cluster B. Nevertheless, a rough correlation is seen between VGP latitude and paleointensity or virtual geomagnetic dipole moment (VDM, see Table 4). This strongly supports the hypothesis that the low-latitude VGPs were recorded during a transitional or excursional field configuration.

\section{Ages and correlation with geomagnetic instability time scale}

K/Ar data obtained from lavas or associated tuffs of our sites give an age interval comprised between 2 and $4 \mathrm{Ma}$ for the Pliocene effusive volcanoes in the Styrian basin (Bojar et al. 2013 and references therein, Table 1). New ${ }^{39} \mathrm{Ar} /{ }^{40} \mathrm{Ar}$-dating performed on samples from 2 localities of our collection was successful for the Klöch and Steinberg volcanoes, which carry transitional directions. They gave weighted locality mean ages of $2.51 \pm 0.27 \mathrm{Ma}$ (Klöch) and $2.46 \pm 0.12 \mathrm{Ma}$ (Steinberg), respectively. The ${ }^{39} \mathrm{Ar} /{ }^{40} \mathrm{Ar}$ ages (Table 3) agree within their error margins and the age average of $2.47 \pm 0.11 \mathrm{Ma}$ allows for correlation with the GPTS (Fig. 13). The transitional lavas are certainly younger than the Gauss-Matuyama reversal and the most likely correspondence is the cryptochron C2r.2r-1 (2.420-2.441 Ma, Cande and Kent 1995). According to Singer (2014; Laj and Channell 2007 and references therein), this is the lowermost geomagnetic excursion in the Matuyama chron and is recorded in marine sediments as well as in terrestrial lava flows on Ouahu, Hawaii (Hawala: 2.51 Ma, Herrero-Bervera et al. 2007; Wheeler Air Force core: 2.46 Ma, Guillou et al.

Table 4 Paleointensity results of the Styrian lavas

\begin{tabular}{|c|c|c|c|c|c|c|c|c|c|c|c|c|}
\hline Location & Latitude $\left({ }^{\circ} \mathrm{N}\right)$ & Longitude ( $\left.{ }^{\circ} \mathrm{E}\right)$ & Name & $\mathrm{D}\left({ }^{\circ}\right)$ & $I\left(^{\circ}\right)$ & $a_{95}\left(^{\circ}\right)$ & Plat $\left({ }^{\circ} \mathrm{N}\right)$ & PLong ( $\left.{ }^{\circ} \mathrm{E}\right)$ & $\mathrm{PI}(\mu \mathrm{T})$ & $s P I(\mu T)$ & $\begin{array}{l}\text { VDM } \\
\left(10^{22}\right. \\
\left.\mathrm{Am}^{2}\right)\end{array}$ & $\begin{array}{l}\text { sVDM } \\
\left(10^{22}\right. \\
\left.\mathrm{Am}^{2}\right)\end{array}$ \\
\hline Altenmarkt & 47.005 & 15.912 & AM03 & 187.6 & -64.3 & 1.9 & -84.7 & 293.7 & 57.4 & 3.4 & 9.3 & 1.1 \\
\hline Stradner Kogel & 46.841 & 15.926 & SK02 & 198.5 & -57.6 & 2.3 & -73.9 & 311.6 & 22.0 & & 3.9 & \\
\hline Waltra & 46.849 & 15.952 & WA02 & 204.8 & -60.6 & 3.3 & -71.5 & 293.4 & 17.4 & 0.5 & 3.0 & 0.2 \\
\hline Klöch 12 & 46.767 & 15.968 & KN12 & 211.6 & -40.1 & 6.2 & -55.2 & 318.3 & 12.0 & 2.0 & 2.6 & 0.8 \\
\hline Klöch 14 & 46.764 & 15.946 & KN14 & 211.8 & -28.8 & 5.7 & -48.9 & 325.2 & 8.6 & 0.7 & 2.0 & 0.3 \\
\hline Klöch 15 & 46.764 & 15.946 & KN15 & 219.2 & -33.5 & 3.8 & -47.1 & 314.1 & 12.9 & 4.2 & 2.9 & 1.9 \\
\hline Tieschen 01 & 46.783 & 15.954 & TD01 & 214.4 & -33.7 & 4.5 & -50.1 & 319.4 & 11.2 & 2.5 & 2.6 & 1.1 \\
\hline Tieschen 03 & 46.787 & 15.956 & TS03/TD04 & 207.9 & -42.2 & 4.3 & -58.4 & 321.4 & 10.5 & 3.9 & 2.2 & 1.6 \\
\hline Steinberg SB & 46.935 & 15.917 & SB01-05 & 200.7 & 28.8 & 4.7 & -25.0 & 353.8 & 4.9 & 2.6 & 1.1 & 1.2 \\
\hline
\end{tabular}



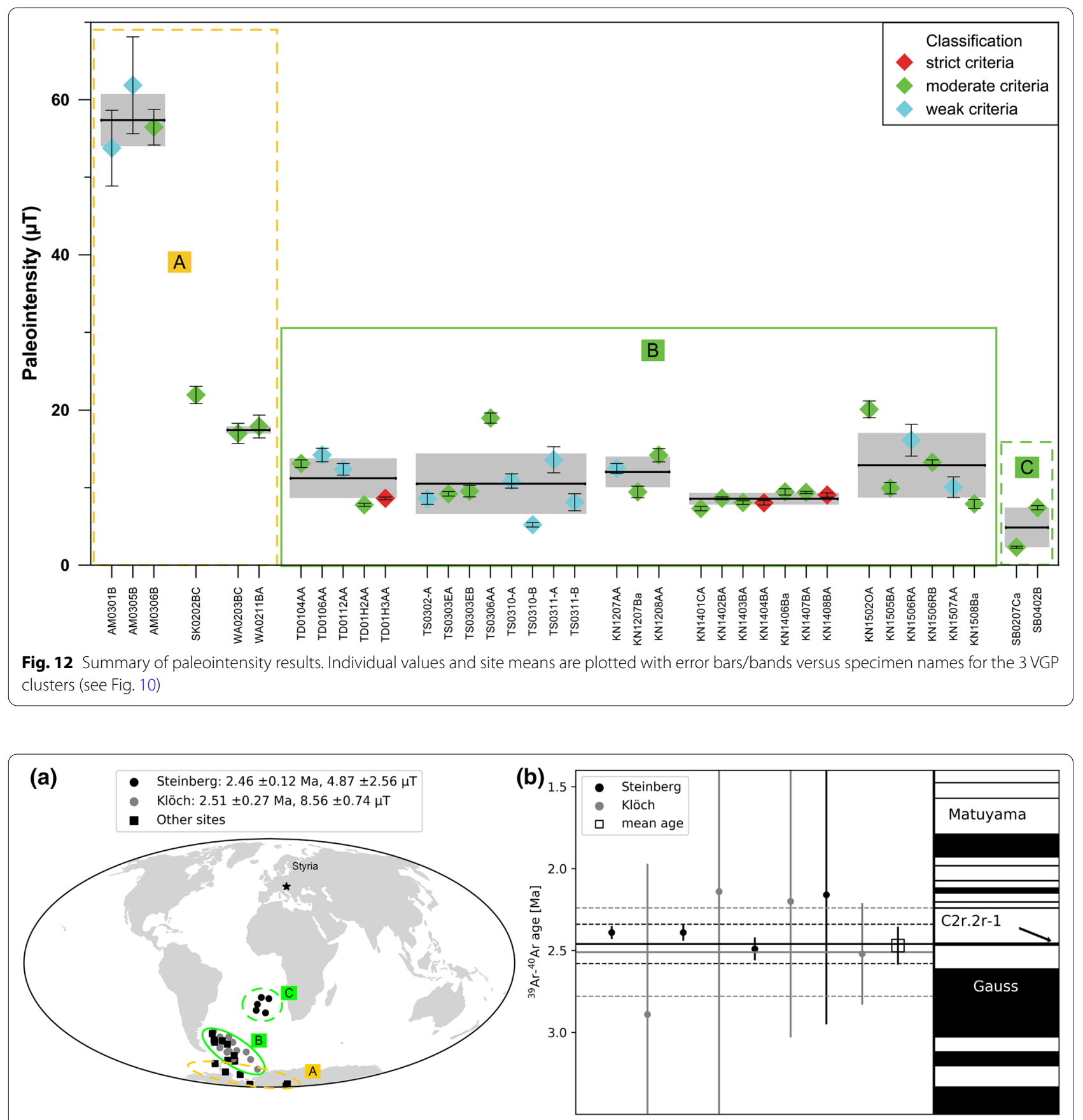

Fig. 13 a Clusters of virtual geomagnetic poles from Styria. $\mathbf{b}^{39} \mathrm{Ar} /{ }^{40} \mathrm{Ar}$-ages with 2 sigma errors from individual samples are shown together with their weighted mean and error band in comparison with the geomagnetic instability time scale (Singer 2014; Ogg et al. 2016)

2018) and on Santiago Island, Cape Verde (2.411 Ma, Knudsen et al. 2009). Guillou et al. (2018) propose $2.46 \pm 0.13 \mathrm{Ma}$ as age of cryptochron C2r.2r-1. Channell et al. (2020) emphasize that excursions have synchronous global manifestation in many cases. Accordingly, our transitional directions provide further evidence of cryptochron C2r.2r-1.

\section{Distribution of VGPs}

The VGP positions of our group B lie in the South Atlantic, east of the Falklands, while those of Steinberg (group C) are found east of St. Helena (Fig. 13). Hoffman (2000) identified the South Atlantic and Central Asia as regions for preferred VGP positions of the Matuyama-Brunhes reversal for North Atlantic marine 
sediments. While different recurrent pole positions west of Australia were found for Tahiti (Hoffman and Singer 2004) and further evidence for this preferred region is presented in a review (Hoffmann et al. 2019) of Cenozoic paleomagnetic transitional field records obtained from lavas in the Southern Hemisphere (e.g., south Indian Ocean, eastern Australia and New Zealand), a subordinate cluster of VGPs in the South Atlantic is present in these studies as well. The situation is different when records from the northern hemisphere are considered (Hoffmann and Singer 2004). Clusters of VGPs in the South Atlantic are found for several transitional records spanning Miocene to Pleistocene ages. They were obtained in the Mediterranean region (Tric et al. 1991; Valet and Laj 1984), the Atlantic Ocean (Riisager et al. 2003, Leonhardt and Soffel 2002) or in California (Glenn et al. 1999). Here the Gauss-Matuyama reversal was recorded. Accordingly, VGP positions associated with transitional field states have been detected in the South Atlantic. Aside from that, the most prominent magnetic anomaly of the present geomagnetic field is situated in South Atlantic and Engbers et al. (2020) provide evidence that anomalous longterm geomagnetic field behavior of this region was already present $\sim 10 \mathrm{Ma}$ ago which can be explained by core-mantle interaction.

Unlike to the two ${ }^{39} \mathrm{Ar} /{ }^{40} \mathrm{Ar}$ ages presented here, the K/Ar ages for the Pliocene Styrian volcanic rocks span a much longer time interval. For instance, two K/Ar ages obtained for Neuhaus volcano (VGP group B) differ from each other (Table 1). Only the younger one overlaps with the new ${ }^{39} \mathrm{Ar} /{ }^{40} \mathrm{Ar}$ age of Klöch, but the intermediate directions suggest that both volcanoes recorded one and the same short-living geomagnetic event. Balogh et al. (1994) already suspected the Neuhaus ages to be overestimated because of excess argon. This is strongly supported by our paleomagnetic and dating results. Another K/Ar age is available for one dike from Königsberg $(2.17 \pm 0.13 \mathrm{Ma}$, Tieschen, Seghedi et al. 2004, see Table 1). It is slightly younger, but overlaps with the new age for Klöch volcano within a two-sigma error $(95 \%$ probability). Hence, all lavas of VGP group B and C could have cooled down in a very short time interval. For the sites Waltra and Stradner Kogel, the low paleointensities (Fig. 13) and the pole positions close the VGP cluster B (Fig. 13) suggest that Stradner Kogel volcano could have been formed shortly before or after the geomagnetic excursion. Accordingly, at least 3 or 4 of the Styrian volcanoes may have been formed in a short time interval corresponding to the duration of a geomagnetic cryptochron. It remains difficult to assign the duration of such an event. According to Cande and Kent (1995), the duration is less than 10 to $30 \mathrm{kyr}$. A recent investigation of the
Laschamp excursion (Cooper et al. 2021) used ancient New Zealand kauri trees for investigating atmospheric radiocarbon and revealed a duration of only 1500 years.

\section{Conclusions}

Paleomagnetic directions from 27 sites from 6 volcanic centers and one volcanic complex of the Styrian volcanic field have been obtained and confirm previous results of Pohl and Soffel (1982). All VGPs have reversed polarity. Only 4 are in the range of secular variation, while the others have low reversed VGP latitudes in the South Atlantic. The anomalous directions cannot be explained by local or regional tectonics. Low paleointensities and ${ }^{39} \mathrm{Ar} /{ }^{40} \mathrm{Ar}$ dating support that all intermediate directions were recorded during an unstable field configuration. The Styrian basalts provide further evidence for cryptochron C2r.2r-1 about 2.4 Ma ago.

\section{Abbreviations}

AF: Alternating field; ChRM: Characteristic remanent magnetization; GPTS: Geomagnetic polarity time scale; IRM: Isothermal remanent magnetization; MDT: Median destructive temperature; MDF: Median destructive field; NRM: Natural remanent magnetization; PCA: Principal component analysis; VSM: Vibration sample magnetometer; VGP:Virtual geomagnetic pole.

\section{Supplementary Information}

The online version contains supplementary material available at https://doi. org/10.1186/s40623-021-01518-w.

Additional file 1: Table S1: Paleointensity results on specimen level. Additional file 2: Table S2: Raw data of ${ }^{39} \mathrm{Ar} /{ }^{40} \mathrm{Ar}$ - incremental heating experiments.

Additional file 3: Table S3: Quality of paleointensity results and outcome of $k(T)$-curves.

Additional file 4: Table S4: Results of hysteresis measurements. Descriptions of data are given within the files.

Additional file 5: Figure S1: $k(T)$-curves (left) and thermal cycling (right). The $k(T)$-curve type is given (see text). One representative example for each type from each site (cf. Table 1 and S3) is shown.

Additional file 6: Figure S2: Directions of NRM (gray, on specimen level) and ChRM (black, on sample level) are plotted together with the mean ChRM (red) and its 95\% confidence circle for each site (cf. Table 1) in equal area stereographic net. Open symbols indicate reversed and closed symbols normal directions. Green stars are the mean ChRMs obtained by Pohl and Soffel (1982) from the same rock unit.

Additional file 7: Figure S3: Histograms of MDT (top) and MDF (bottom) for the Steinberg site (left) and the Klöch site (right).

Additional file 8: Figure S4: Additional information of paleointensity experiments of Fig. 8. NRM decay curve (left) with results of the tail checks, and plots of angular difference of $H_{L}$-pTRM (upper middle), $\delta$ CK is the relative check error normalized to the TRM (lower middle), $\delta t *$ is the normalized tail of pTRM corrected for the angular difference between the applied field and the NRM (upper right) and $\delta$ TR is the difference between first and repeated demagnetization (lower right).

Additional file 9: Figure S5: ${ }^{39} \mathrm{Ar} /{ }^{40} \mathrm{Ar}$ - incremental heating experiments with degassing spectra (left) and inverse isochron plots (right). a) to d) samples from Klöch volcano and e) to j) samples from Steinberg volcano. 


\section{Acknowledgements}

Extensive sampling was possible in the quarries of Mühldorf and Hochstraden thanks to permission of Dipl.-Ing. Christian Appel (Steirische Basalt- u. Hartgesteinwerke) and in Klöch quarry thanks to permission of Geschäftsführer Otto Nell (ALAS Klöch GmbH). Some of the samples were cut and demagnetized in the paleomagnetic laboratory of the LIAG (Grubenhagen), ES kindly acknowledges cooperation with Christian Rolf. The sites of Klöch volcano were investigated by Maria Nievoll in her master thesis and those of Tieschen by Julia McLaughlin in her bachelor thesis under supervision of RS. Julia McLaughlin, Oliver Pöschl, Arno Ammerer and Timo Krause helped to perform the paleomagnetic measurements. Thank you to Martin Gross who provided the geological map of (Fig. 1). Suggestions of two anonymous reviewer helped to improve the original version of the paper.

\section{Authors' contributions}

Field work was done by ES, PA, IF, RS and RL. Paleo and rock magnetic results were produced by ES, PA, RS and RE. Dating was performed by MG. ES wrote the paper with contributions of PA, IF, MG and RS. All authors read and approved the final manuscript.

\section{Funding}

The study was supported by Austrian science fund, Grant P 30523.

\section{Availability of data and materials}

The directional and paleointensity data associated with this publication are available from https://github.com/Paleolnt/EPS-2021-Styria/.

\section{Declarations}

Ethics approval and consent to participate

Not applicable.

\section{Consent for publication}

Not applicable.

\section{Competing interests}

The authors declare that they have no competing interests.

\section{Author details}

1Palaeomagnetic Laboratory Gams, Chair of Applied Geophysics, Montanuniversität Leoben, Gams 45, 8130 Frohnleiten, Austria. ${ }^{2}$ Conrad Observatorium, ZAMG-Zentralanstalt für Meteorologie und Geodynamik, Hohe Warte 38, 1190 Vienna, Austria. ${ }^{3}$ Geological Survey of Norway, Torgarden, P.O. Box 6315, 7491 Trondheim, Norway. ${ }^{4}$ Universalmuseum Joanneum, Studienzentrum Naturkunde, Weinzöttlstraße 16,8045 Graz, Austria.

Received: 8 April 2021 Accepted: 14 September 2021

Published online: 03 October 2021

\section{References}

Arneitz P, Leonhardt R, Schnepp E, Heilig B, Mayrhofer F, Kovacs P, Hejda P, Valach F, Vadasz G, Hammerl C, Egli R, Fabian K, Kompein N (2017) The HISTMAG database: combining historical, archaeomagnetic and volcanic data. Geophys J Int 210:1347-1359. https://doi.org/10.1093/gji/ggx245

Balogh K, Ebner F, Ravasz C (1994) K/Ar-Alter tertiärer Vulkanite der südöstlichen Steiermark und des südlichen Burgenlandes. In: Lobitzer H, Csaszar G, Daurer A (eds) Jubiläumsschrift 20 Jahre Geologische Zusammenarbeit Österreich-Ungarn. 2. Geologische Bundesanstalt, Wien, p 55

Béguin A, Paterson G, Biggin AJ, de Groot L (2020) Paleointensity.org: an online, opensource, application for the interpretation of paleointensity data. Geochem Geophys Geosyst 21. https://doi.org/10.1029/2019G C008791

Biggin AJ, Perrin M, Dekkers MJ (2007) A reliable absolute palaeointensity determination obtained from a non-ideal recorder. Earth Planet Sci Lett 257:545-563. https://doi.org/10.1016/j.epsl.2007.03.017

Bojar H-P, Bojar A-V, Hałas S, Wójtowicz A (2013) K/Ar geochronology of igneous amphibole phenocrysts in Miocene to Pliocene volcanoclastics,
Styrian Basin, Austria. Geol Quart 57:405-416. https://doi.org/10.7306/ gq. 1102

Bono RK, Tarduno JA, Nimmo F, Cottrell RD (2019) Young inner core inferred from Ediacaran ultra-low geomagnetic field intensity. Nature Geosci 12:143-147. https://doi.org/10.1038/s41561-018-0288-0

Cande SC, Kent DV (1995) Revised calibration of the geomagnetic polarity time scale for the late Cretaceous and Cenozoic. J Geophys Res 100:583-587. https://doi.org/10.1029/94JB03098

Channell JET, Xuan C, Hodell DA (2009) Stacking paleointensity and oxygen isotope data for the last 1.5 Myr (PISO-1500). Earth Planet Sci Lett 283:14-23. https://doi.org/10.1016/j.epsl.2009.03.012

Channell JET, Singer BS, Jicha BR (2020) Timing of Quaternary geomagnetic reversals and excursions in volcanic and sedimentary archives. Quat Sci Rev 228:106114. https://doi.org/10.1016/j.quascirev.2019.106114

Coe RS (1967) Palaeo-intensity of the Earth's magnetic field determined from tertiary and quaternary rocks. J Geophys Res 72:3247-3262. https://doi. org/10.1029/JZ072i012p03247

Coe RS, Grommé SC, Mankinen EA (1978) Geomagnetic paleointensities from radiocarbon-dated lava flows on Hawaii and the question of the Pacific nondipole low. J Geophys Res 83:1740-1756. https://doi.org/10.1029/ JB083iB04p01740

Cooper A, Turney CSM, Palmer J, Hogg A, McGlone M, Wilmshurst J, Lorrey AM, Heaton TJ, Russell JM, McCracken K, Anet JG, Rozanov E, Friedel M, Suter I, Peter T, Muscheler R, Adolphi F, Dosseto A, Faith JT, Fenwick P, Fogwill CJ, Hughen K, Lipson M, Liu J, Nowaczyk N, Rainsley E, Bronk Ramsey C, Sebastianelli P, Souilmi Y, Stevenson J, Thomas Z, Tobler R, Zech R (2021) A global environmental crisis 42,000 years ago. Science 371:811-818. https://doi.org/10.1126/science.abb8677

Cromwell G, Tauxe L, Staudigel H, Ron H (2015) Paleointensity estimates from historic and modern Hawaiian lava flows using glassy basalt as a primary source material. Phys Earth Planet Int 241:44-56. https://doi.org/10. 1016/j.pepi.2014.12.007

Day R, Fuller M, Schmidt VA (1977) Hysteresis properties of titanomagnetites: grain-size and compositional dependence. Phys Earth Planet Int 13:260-267. https://doi.org/10.1016/0031-9201(77)90108-X

Dunlop D (2002) Theory and application of the Day plot (Mrs/Ms versus Hcr/ $\mathrm{Hc})$, 2, Application to data for rocks, sediments and soils. J Geophys Res 107:EPM5-1-15. https://doi.org/10.1029/2001JB000487.

Ebner F, Sachsenhofer RF (1991) Die Entwicklungsgeschichte des Steirischen Tertiärbeckens. Mitteilungen Der Abteilung Für Geologie Und Paläontologie Am Landesmuseum Joanneum 49:1-96

Engbers YA, Biggin A, Bono RK (2020) Significantly high palaeomagnetic dispersion suggests long-lived anomalous behavior in the South Atlantic. Proc Natl Acad Sci 117:18258-18263. https://doi.org/10.1073/pnas.20012 17117

Fisher RA (1953) Dispersion on a sphere. Proc R Soc London 27:295-305. https://doi.org/10.1098/rspa.1953.0064

Fritz I (1992) Geomagnetische Untersuchungen an Vulkaniten aus dem Bereich Altenmarkt bei Riegerburg (Oststeirisches Neogenbecken). Mitteilungen Naturwissenschaftlicher Verein Steiermark 122:29-37

Fritz I (1996) Notes on the Plio-/Pleistocene volcanism of the Styrian Basin. Mitteilungen Der Gesellschaft Der Geologie- Und Bergbaustudenten in Österreich 41:87-100

Glen JMG, Coe RS, Liddicoat JC (1999) A detailed record of paleomagnetic field change from Searles Lake, California:2. The Gauss/Matuyama polarity reversal. J Geophys Res 104:12883-12894. https://doi.org/10.1029/1999J B900048

Gradstein M, Ogg JG, Schmitz M, Ogg G (2012) The geologic time scale 2012. Elsevier, Amsterdam

Gross M, Fritz I, Piller WE, Soliman A, Harzhauser M, Hubmann B, Moser B, Scholger R, Suttner TJ, Bojar H-P (2007) The neogene of the Styrian Basin, guide to excursions. Joannea Geol Paläont 9:117-193

Gubbins D, Herrero-Bervera E (2007) Encyclopedia of geomagnetism and paleomagnetism. Springer, Dordrecht

Guillou H, Scao V, Nomade S (2018) ${ }^{40} \mathrm{Ar} /{ }^{39}$ Ar age of cryptochron C2r.2r-1 as recorded in a lava sequence within the Ko'olau volcano (Hawaii, USA). Quat Geochronol 43:91-101. https://doi.org/10.1016/j.quageo.2017.10. 005

Herrero-Bervera E, Browne E, Valet JP, Singer BS, Jicha BR (2007) Cryptochron C2r.2r-1 recorded 2.51 Ma in the Koolau Volcano at Halawa, Oahu, 
Hawaii, USA: paleomagnetic and ${ }^{40} \mathrm{Ar} /{ }^{39} \mathrm{Ar}$ evidence. Earth Planet Sci Lett 254:256-271. https://doi.org/10.1016/j.epsl.2006.11.023

Hoffman KA (2000) Temporal aspects of the last reversal of Earth's magnetic field. Phil Tran R Soc Lond A 358:1 181-1190. https://doi.org/10.1098/rsta. 2000.0580

Hoffman KA, Camps P, Carlton M (2019) Rare palaeomagnetic evidence of long-term mantle control of the geodynamo and possible role of the NAD field in the reversal process. Geophys J Int 221:142-150. https://doi. org/10.1093/gji/ggz480

Hoffman KA, Singer BS (2004) Regionally recurrent paleomagnetic transition fields and mantle processes. In: Channell JET, Kent DV, Lowrie W, Meert JG (eds) Timescales of the Paleomagnetic Field. AGU, Geophysical Monograph. vol. 145. American Geophysical Union. https://doi.org/10. 1029/145GM17.

Kirschvink JL (1980) The least squares line and plane and the analysis of paleomagnetic data. Geophys J R Astr Soc 62:699-718. https://doi.org/10. 1111/j.1365-246X.1980.tb02601.x

Kissel C, Laj C (2004) Improvements in procedure and paleointensity selection criteria (PICRIT-03) for Thellier and Thellier determinations: application to Hawaiian basaltic long cores. Phys Earth Planet Int 147:155-169. https:// doi.org/10.1016/j.pepi.2004.06.010

Knudsen MF, Holm PM, Abrahamsen N (2009) Paleomagnetic results from a reconnaissance study of Santiago (Cape Verde Islands): identification of cryptochron C2r.2r-1. Phys Earth Planet Int 173:279-289. https://doi.org/ 10.1016/j.pepi.2009.01.009

Kollmann K (1965) Jungtertiär im Steirischen Becken. Mitteilungen Der Geologischen Gesellschaft Wien 57:479-632

Krása D, Heunemann C, Leonhardt R, Petersen N (2003) Experimental procedure to detect multidomain remanence during Thellier-Thellier experiments. Phys Chem Earth 28:681-687. https://doi.org/10.1016/ S1474-7065(03)00122-0

Laj C, Channell JET (2007) Geomagnetic Excursions. Treat Geophys 5:373-416. https://doi.org/10.1016/B978-044452748-6.00095-X

Lee JY, Marti K, Severinghaus JP, Kawamura K, Yoo HS, Lee JB, Kim JS (2006) A redetermination of the isotopic abundances of atmospheric Ar. Geochim Cosmochim Acta 70:4507-4512. https://doi.org/10.1016/j.gca.2006.06. 1563

Leonhardt R, Soffel HC (2002) A reversal of the Earth's magnetic field recorded in mid Miocene lava flows of Gran Canaria, Paleointensities. J Geophys Res 107:2299. https://doi.org/10.1029/2001JB000949

Leonhardt R, McWilliams M, Heider F, Soffel HC (2009) The Gilsá excursion and the Matuyama/Brunhes transition recorded in ${ }^{40} \mathrm{Ar} /{ }^{39} \mathrm{Ar}$ dated lavas from Lanai and Maui, Hawaiian Islands. Geophys J Int 179:43-58. https://doi. org/10.1111/j.1365-246X.2009.04264.X

Leonhardt R, Heunemann C, Krása D (2004) Analyzing absolute paleointensity determinations: acceptance criteria and the software ThellierTool4.0. Geochem Geophys Geosys 5. https://doi.org/10.1029/2004GC000807

Marshall M, Chauvin A, Bonhommet N (1988) Preliminary paleointensity measurements and detailed magnetic analyses of basalts from the Skalamaelifell excursion, southwest Iceland. J Geophys Res 93:11681-11698. https://doi.org/10.1029/JB093iB10p11681

Mauritsch H (1972) Paläomagnetische Messungen an west- und oststeirischen Vulkaniten. Archiv Für Lagerstättenforschung in Den Ostalpen 13:35-57

McDougall I, Harrison TM (1999) Geochronology and thermochronology by the ${ }^{40} \mathrm{Ar} /{ }^{39} \mathrm{Ar}$ method. Oxford University Press, New York

Muxworthy AR (2017) Considerations for latitudinal time-averaged-field Palaeointensity analysis of the last five million years. Front Earth Sci 5:79. https://doi.org/10.3389/feart.2017.00079
Neubauer F, Genser J (1990) Architektur und Kinematik der östlichen Zentralalpen - eine Übersicht. Mitteilungen Des Naturwissenschaftlichen Vereines Für Steiermark 120:203-219

Ogg JG, Ogg GM, Gradstein FM (2016) A concise geologic time scale: 2016. Elsevier, Amsterdam

Paterson GA, Tauxe L, Biggin AJ, Shaar R, Jonestrask LC (2014) On improving the selection of Thellier-type paleointensity data. Geochem Geophys Geosyst 15:1180-1192. https://doi.org/10.1002/2013GC005135

Paterson GA, Biggin AJ, Hodgson E, Hill MJ (2015) Thellier-type paleointensity data from multidomain specimens. Phys Earth Planet Int 245:117-133. https://doi.org/10.1016/j.pepi.2015.06.003

Pohl J, Soffel HC (1982) Paleomagnetism of tertiary volcanics of Styria (Austria). Geol Jahrb 52:137-147

Pöschl I (1991) A model for the depositional evolution of the volcanoclastic succession of a pliocene maar volcano in the Styrian Basin (Austria). Jahrb Geol Bundesanst 134:809-843

Prévot M, Mankinen EA, Coe RS, Grommé CS (1985) The Steens Mountain (Oregon) geomagnetic polarity transition, 2. Field intensity variations and discussion of reversal models. J Geophys Res 90:10417-10448. https:// doi.org/10.1029/JB090iB12p10417

Renne PR, Mundil R, Balco G, Min K, Ludwig KR (2010) Joint determination of ${ }^{40} \mathrm{~K}$ decay constants and ${ }^{40} \mathrm{Ar}^{*} / \mathrm{H}^{40} \mathrm{~K}$ for the Fish Canyon sanidine standard, and improved accuracy for ${ }^{40} \mathrm{Ar} /{ }^{39} \mathrm{Ar}$ geochronology. Geochim Cosmochim Acta 74:5349-5367. https://doi.org/10.1016/j.gca.2010.06.017

Riisager P, Riisager J (2001) Detecting multidomain magnetic grains in Thellier paleointensity experiments. Phys Earth Planet Int 125:111-117. https:// doi.org/10.1016/50031-9201(01)00236-9

Riisager J, Riisager P, Pedersen AK (2003) The C27n-C26r geomagnetic polarity reversal recorded in the west Greenland flood basalt province: how complex is the transitional field? J Geophys Res 108(B3):2155. https://doi. org/10.1029/2002JB002124

Seghedi I, Downes H, Vaselli O, Szakács A, Balogh K, Pécskay Z (2004) Postcollisional tertiary-quaternary mafic alkalic magmatism in the CarpathianPannonian region: a review. Tectonophysics 393:43-62. https://doi.org/ 10.1016/j.tecto.2004.07.051

Shaar R, Tauxe L (2013) Thellier gui: an integrated tool for analyzing paleointensity data from Thellier-type experiments. Geochem Geophys Geosyst 14:677-692. https://doi.org/10.1002/ggge.20062

Singer BS (2014) A Quaternary geomagnetic instability time scale. Quat Geochronol 21:29-52. https://doi.org/10.1016/j.quageo.2013.10.003

Tauxe L, Shaar R, Jonestrask L, Swanson-Hysell NL, Minnett R, Koppers AAP, Constable CG, Jarboe N, Gaastra K, Fairchild L (2016) PmagPy: software package for paleomagnetic data analysis and a bridge to the Magnetics Information Consortium (MaglC) Database. Geochem Geophys Geosyst 17:2450-2463. https://doi.org/10.1002/2016GC006307

Tric E, Laj C, Valet JP, Tucholka P, Paterne M, Guichard F (1991) The Blake geomagnetic event: transition geometry, dynamical characteristics and geomagnetic significance. Earth Planet Sci Lett 102:1-13. https://doi.org/ 10.1016/0012-821X(91)90013-8

Valet JP, Laj C (1984) Invariant and changing transition field configurations in a sequence of geomagnetic reversals. Nature 311:552-555. https://doi.org/ $10.1038 / 311552 \mathrm{a} 0$

\section{Publisher's Note}

Springer Nature remains neutral with regard to jurisdictional claims in published maps and institutional affiliations. 